\title{
Bilişim Teknolojileri Öğretmenlerinin Kodlama Öğretimine İlişkin Görüşleri: Manisa Örneği ${ }^{*}$
}

\author{
Figen Eğin² ve Y. Deniz Arıkan ${ }^{3 * * 4}$
}

\section{Öz}

$\mathrm{Bu}$ araştırmanın amacı Bilişim Teknolojileri öğretmenlerinin, ortaokul düzeyinde kodlama öğretiminde kullandıkları kodlama araçlarına, öğretim yöntemlerine ve ölçme değerlendirme etkinliklerine ilişkin görüşlerini belirlemek ve kodlama öğretimi ile çeşitli değiş̧kenler arasındaki uyumu incelemektir. Araştırma karma araştırma deseninde gerçekleştirilmiş̧ir. Araştırma kapsamında ilk olarak araştırmacılar tarafindan hazırlanan Bilișim Teknolojileri Öğretmenlerinin Kodlama Öğretimine İlişkin Görüșleri Anketi ile 105 Bilişim Teknolojileri öğretmeninin kodlama araçları, öğretim yöntemleri, ölçme ve değerlendirme araçlarına ilişskin görüşleri alınmıştır. Ardından 9 Bilişim Teknolojileri öğretmeni ile yarı-yapılandırılmış görüşmeler gerçekleştirilmiştir. Araştırmada nicel verilerin analizinde frekans, yüzde ve uyum analizi kullanılmış, nitel verilerin analizinde ise içerik analizi kullanılmıştır. Araştırmanın bulgularına göre Bilişim Teknolojileri öğretmenlerinin kodlama öğretiminde en çok blok tabanlı ve robotik kodlama araçlarını; gösterip yaptırma, oyun ve problem tabanlı öğretim etkinliklerini kullandıkları görülmüştür. Bilişim Teknolojileri öğretmenleri kodlama öğretiminde ölçme ve değerlendirme etkinliklerinde en çok uygulama sınavı, proje ve öğrenci ürün dosyası kullanmaktadırlar. Nicel veriler üzerinde yapılan analizler sonucunda Bilișim Teknolojileri öğretmenlerinin kodlama öğretimi deneyimi ile kullanılan ölçme ve değerlendirme araçları arasında anlamlı bir ilişki olduğu görülmüștür.

\author{
Anahtar Sözcükler \\ Kodlama \\ Kodlama öğretimi \\ Bilgisayar bilimleri \\ eğitimi \\ Makale Hakkında \\ Gönderim Tarihi \\ 03 Haziran 2020 \\ Kabul Tarihi \\ 15 Haziran 2020 \\ Makale Türü \\ Araştırma Makalesi
}

DOI: $10.12984 /$ egeefd.747629

\section{Information Technologies Teachers' Opinions on Coding Teaching: Sample of Manisa*}

\section{Abstract}

Keywords

The aim of this research is to examine the opinions of ICT teachers who work in middle schools in Turkey about the tools, teaching methods, and assessment and evaluation instruments that they use in coding education and to investigate the compatibility between coding education and various variables. The research was designed in a mixed-methods. First, the data on coding tools, teaching methods, and assessment and evaluation instruments used for coding teaching were collected from 105 ICT teachers with the "Opinions of Information Technology Teachers on Coding Education" questionnaire. Then, semi-structured interviews were held with 9 ICT teachers. Frequency, percentage, and correspondence analysis were performed to analyze quantitative data, and content analysis method was used to analyze qualitative data. According to the findings of the research, ICT teachers mostly use block-based and robotic coding tools, and demonstration and game-based learning and problem-based learning activities. ICT Teachers mostly use practice exams, projects, and student product files for assessment and evaluation. As a result of the analysis on quantitative data it was found that there was a significant relationship between the experience of coding teaching and the assessment and evaluation instruments used.

\section{Coding}

Coding teaching Computer science education

Article Info

Received

June 03,2020

Accepted

June 15,2020

Article Type

Research Paper

Attf: Eğin, F. ve Arıkan, Y. D. (2020). Bilişim teknolojileri öğretmenlerinin kodlama öğretimine ilişkin görüşleri: Manisa örneği. Ege Eğitim Dergisi, 21(2), 57-75. doi: 10.12984/egeefd.747629

\footnotetext{
* Bu çalışma, Figen Eğin tarafından Dr. Öğr. Üyesi Y. Deniz Arıkan danışmanlığında hazırlanan yüksek lisans tezinden üretilmiştir. [This study was produced from master thesis prepared by Figen Eğin under the supervision of Assist. Prof. Y. Deniz Arıkan.]

1 단 Milli Eğitim Bakanlığı, Manisa/Turgutlu Bilim Sanat Merkezi, Türkiye, figenkaya@gmail.com

${ }^{* *}$ Sorumlu Yazar/Corresponding Author

2 Ege Üniversitesi, Eğitim Fakültesi, Bilgisayar ve Öğretim Teknolojileri Eğitimi Bölümü, Türkiye, y.deniz.arikan@gmail.com
} 


\section{Extended Abstract}

\section{Introduction}

More and more countries are updating their curriculum to include coding skills as a part of computer science education. In addition, many non-profit projects are executed to teach students coding from a young age (Williamson, Bergviken Rensfeldt, Player-Koro \& Selwyn, 2019). Recently, education programs at all levels in Turkey have been regulated to include coding skills (Ministry of National Education [MoNE], 2020). In addition, projects supporting computer science education have started to be implemented in many provinces by Governorships or Provincial Directorates of National Education. It can be said that the increasing need for labor in the field, advances in technology, or the ongoing technological race among countries along with Industry 4.0 has been effective in increasing the importance of computer science education. It is argued that it is inevitable to start computer science education from a young age along with the technology which started to take place in every area of our lives (Grover, 2014). The application of computer science education from an early age is also important in terms of being a helpful tool for students to acquire as 21 st century skills (Chao, 2016).

As a result of computer science education gaining such importance, many tools that can be used in this field have emerged, and researches have started question as to how this education can be delivered in the most effective way (Fokides, 2017; Jenson \& Droumeva, 2016; Hansen, Iveland, Carlin, Harlow, \& Franklin, 2016). At this point, it would be beneficial to examine the opinions of the information technology (ICT) teachers about how to deliver computer science education more effectively, because they have experience both about the tools they use in coding teaching and also teaching and assessment methods. Based on this idea, the aim of this study is to examine the opinions of ICT teachers working in secondary schools in Manisa regarding the tools they use in coding teaching and teaching and assessment methods.

\section{Method}

This research was conducted in a sequential explanatory design, a sub-design of the mixed design. In the sequential explanatory design, quantitative data is collected first, and then qualitative data are collected to gather detail on these data. In this research, first of all, the opinions of the ICT teachers about the tools, teaching and evaluation methods used in coding teaching were examined. Qualitative interviews were conducted using the prompts in the semi-structured interview form developed by the researcher in order to examine the obtained data in depth. The universe of this research consists of approximately 150 ICT teachers working in secondary schools in the province of Manisa. In the quantitative part of the research, almost the entire universe has been reached; data collected from 105 teachers who responded to the questionnaire with a cross-sectional screening model were reported with frequency tables. Correspondence analysis was used to examine the relationship between teachers' professional experience, coding education experiences, the training they received, and the coding tools they find effective teaching methods and assessment instruments. The reason why correspondence analysis is preferred in this research is that there are many data categories. It is ensured that the relationships between variables can be analyzed with multidimensional cross tables by correspondence analysis (Kılıç, 2016). In the qualitative part of the study, 9 teachers who have been teaching coding for at least three years were purposefully selected. A semi-structured interview form was prepared to collect qualitative data. This form was evaluated by 4 experts. A pilot interview was held with the form obtained as a result of expert evaluations, and the form was finalized after the pilot interview. After the qualitative interviews were conducted, the data were dumped and these inventories were sent to the participants and confirmed. The data obtained were analyzed by content analysis. In order to ensure the content validity of the interviews, both the researcher and a Computer Education and Instructional Technology (CEIT) specialist coded the data, and the themes were revised by looking at the compatibility between them. In order to prevent validity and reliability problems, the researcher analyzed the data by considering the information obtained from the relevant literature and using his experience in the field as an ICT teacher.

\section{Findings}

As a result of the research, it was found that teachers thought that block-based coding tools and robotic tools were effective. Among these tools, although code.org, Scratch, and Arduino tools appear to be prominent, teachers also frequently use mBlock and $\mathrm{mBot}$ tools. As a result of qualitative research conducted to reveal the reasons for these preferences of teachers, two themes were obtained. These themes are the outcomes of the educational process and its contribution to the educational process. Under the outcomes of the educational process theme, sub-themes are increasing productivity, gaining thinking skills, being fun, convenience, visuality, easy to difficult ordering of activities, and suitability for student level. Under the benefit it provides to the education and training process 
theme, sub-themes are being fun, ease, visuality, ordering activities from easy to difficult, and suitability to student level.

Compared to other teaching methods in coding teaching of teachers, it is seen that they find the methods and activities of game-based learning, demonstration, and game writing more effective. The method they found the least effective was the method of expression. When the reasons for these opinions of the teachers were examined, it was found that the themes of enriching learning, providing permanent learning, and environmental conditions emerged as the reasons for using these teaching methods and activities.

When teachers' opinions about assessment and evaluation instruments were examined, the most used tools were practice exams, projects, and student product files, respectively. It is seen that teachers use oral exams the least. It was found that the teachers considered the possibility of evaluating the process and the self-assessment opportunity when deciding on the methods of assessment and evaluation. As a result of the correspondence analysis, it was found that teachers with 5 years or more coding teaching experience used self-assessment forms more than other teachers.

\section{Discussion and Conclusion}

It was seen that the teachers participating in the research found block-based coding tools and robotic coding tools more effective. Among these tools, code.org, Scratch, and Arduino tools stand out the most and mBot and mBlock follow them. Block-based coding environment makes it easier for students to perceive concepts and offers ease of use with its simple structure. According to the qualitative research results, teachers tend to use these tools due to their ease, visuality, suitability to the student level as well as being fun. When the literature is examined, it is seen that block-based programming tools are recommended at K12 level because it minimizes misconceptions (Mladenović, Boljat, \& Žanko, 2018). In this respect, teachers' views are parallel to the literature.

The teachers in the research mostly preferred the methods of demonstration, game-based programming, writing, and discovering games. When the methods used by teachers are examined in the literature, it is seen that the demonstration method is used frequently (Akbıyık \& Seferoğlu, 2012). Additionally, it is seen that teaching by giving game programming tasks to students is beneficial (Fokides, 2017; Jenson \& Droumeva, 2016; Nouri, Norén, \& Skog, 2018). In addition, teaching methods such as digital story writing (Hansen et al., 2016) and mobile application development (John \& Rani, 2015) are seen to be applied. Teachers prefer these teaching methods to enrich the learning environment and provide permanent learning. Also, it was observed that teachers consider environmental conditions while choosing the teaching method and teachers who teach in adverse conditions tend towards more classical teaching methods.

Teachers participating in the research mostly use application exam, project, and student product files as assessment tools. According to the qualitative findings, it was observed that teachers were looking for the process evaluation feature in the assessment and evaluation instrument. In the literature, it was determined that emphasis was placed on the formative assessment used to evaluate the process in computer science (Grover, 2014; Kong, 2016; Kotibi $\&$ Tzelepi, 2015). Another feature that teachers are looking for in the assessment and evaluation tool is the selfassessment opportunity. According to Yeni (2017)' self-assessment forms, which allow students to control their own learning processes, are an important part of evaluation in coding teaching. In addition, it has been observed that teachers who have been giving computer science education for 5 years and longer use self-assessment more. It is thought that as teachers gain experience, they see the positive effect of self-assessment more.

While this research was in progress, it was observed that teachers should be supported mostly in measurement and evaluation. Considering that measurement and evaluation are one of the most important parts of teaching, it is thought that it will be appropriate for researchers to develop measurement tools in this field in order to make measurement analytical in the field of coding teaching. 


\section{Giriş}

Günümüzde pek çok ülkenin öğretim programlarını kodlama becerilerini kapsayacak şekilde güncellediği ve birçok kuruluşun kodlamayı küçük yaşlardan itibaren öğrencilere öğretmek için girişimlerde bulunduğu görülmektedir (Williamson, Bergviken Rensfeldt, Player-Koro ve Selwyn, 2019). Bilgisayar bilimleri eğitiminin temel alanlarından biri programlama dillerinin öğrenimi ve yazılım geliştirmedir (Encyclopedia Britannica, 2020). Programlama eğitiminin kü̧̈ük yaşlardan itibaren verilmesi yeni bir fikir olmamakla beraber (Forsythe, 1967) son dönemde bu alandaki girişimlerin yoğunluk kazandığı söylenebilir. Örneğin Fransa ve Finlandiya'nın aralarında bulunduğu 16 Avrupa ülkesi müfredatlarına kodlama öğretimini eklerken (Balanskat ve Engelhardt, 2015); Singapur, Avustralya, Güney Kıbrıs ve Güney Kore gibi ülkeler de bu alanda açık politikalar belirlemişlerdir (Bers, 2017; Özçakmak, 2014; Webb ve diğ., 2017). İsrail'de ise ilkokul 4.sınıf düzeyinden itibaren kodlama öğrenimine yönelik bir öğretim programının uygulandığı görülmektedir (Armoni ve Gal-Ezer, 2014). Uluslararası düzeyde herkesin erişimine açık olan code.org ve scratch.mit.edu gibi projeler de okul öncesi dönemden itibaren, binlerce öğrencinin kodlama öğrenmelerini desteklemek üzere kâr amacı gütmeden hizmet sunmaktadır (Bers, 2017).

Türkiye'de uygulanan öğretim programları incelendiğinde ise 5. ve 6. sınıf düzeyinde "Bilişim Teknolojileri ve Yazılım", ortaöğretim düzeyinde "Bilgisayar Bilimleri" dersleri kapsamında öğrencilere algoritma tasarlama ve yazılım geliştirme becerilerinin kazandııılmasının hedeflendiği görülmektedir. Üstün yetenekli ve özel yetenekli öğrencilerin örgün eğitimlerine ek olarak eğitim alabildikleri Bilim ve Sanat Merkezlerinde (BİLSEM) uygulanan Bilgisayar Dersi Çerçeve Programı ağırlıklı olarak programlama dillerinin öğretimini içermektedir (Milli Eğitim Bakanlığı [MEB], 2020). Buna ilişkin, yükseköğretimdeki öğretmen yetiştirme programlarında da öğretmen adaylarının bu alandaki yeterliliklerini arttırmak üzere birtakım düzenlemelerin yapıldığı görülmektedir (Yükseköğretim Kurulu [YÖK], 2018). Ayrıca, Türkiye'de Valilikler veya Milli Eğitim Müdürlüklerinin desteğiyle yürütülen, bilgisayar bilimleri eğitimini yaygınlaştırmayı hedefleyen birçok proje de bulunmaktadır. Bunların arasında, Manisa Valiliği tarafından desteklenmekte olan Kodla(Ma)nisa Projesi; il sınırları içerisindeki tüm ortaokulları kapsaması, kurulan 18 kodlama atölyesi, uygulanan eğitmen eğitimleri ve düzenlenen etkinlikler ile dikkat çekmektedir (KodlaManisa, 2020a).

Son dönemde bilgisayar bilimleri eğitiminin bu denli yaygınlaşması ve kodlama öğretiminin önemsenmesinde teknoloji alanında söz sahibi olmak isteyen ülkeler arasındaki rekabetin ve Endüstri 4.0 kavramı ile birlikte artan iş gücü ihtiyacının karşılanmasına yönelik girişimlerin etkili olduğu söylenebilir. Ayrıca bilgisayar bilimleri eğitimi kapsamında gerçekleştirilen kodlama etkinliklerinin, bilgi işlemsel düşünme ve problem çözme gibi becerilerinin kazandırılması için gerekli olduğunun altı çizilmektedir (Au ve Leung, 1992; Chao, 2016; Clements ve Gullo, 1984, Fessakis, Gouli ve Mavroudi, 2013; Kalelioğlu ve Gülbahar, 2014). Öte yandan, bu girişimlerin amacına ulaşabilmesinin öğrenme - öğretme sürecinin niteliği ile yakından ilişkili olduğu ifade edilebilir. Bashir ve Hoque (2016) kodlama öğretimi için etkin bir pedagoji geliştirilmesinin önemini vurgulamışlardır. Kodlama eğitimine ilişkin alanyazındaki çalışmaların bir ksımı da öğretmenlere ve öğretmen adaylarına yönelik yapılmıştır (Kong, Li ve Kwok, 2018; Pala ve Mihc1-Türker, 2019; Mihc1-Türker ve Pala, 2018; Uzgur ve Aykaç, 2016). Bu çalışmalarda öğretmenlerin görüşlerinin ve kodlama öğretimine ilişkin yeterliklerinin incelendiği görülmektedir. Kodlama öğretiminde uygulanan yöntem ve kullanılan araçlara yönelik olarak alanyazın incelendiğinde birçok farklı yöntem ve araçtan yararlanıldığı görülmektedir (Fokides, 2017; Hansen ve diğ., 2016; Jenson ve Droumeva, 2016).

\section{Kodlama Öğretimi ve Araçlar}

Birçok alanın öğretiminde olduğu gibi bilgisayar bilimleri eğitimi ve kodlama öğretiminde de farklı yaklaşımlar uygulanmaktadır. Alanyazında, bilgisayar bilimleri eğitiminde oyun programlama yaklaşımının sıklıkla denendiği (Fokides, 2017; Jenson ve Droumeva, 2016), araç kitleriyle öğretimin yapıldığı (Arabacıoğlu, Bülbül ve Filiz, 2007; Raab, Rasala ve Proulx, 2000), öğrencilerin öğrenme nesneleri tasarladığı (Abad, 2008), dijital hikâye yazdığı (Hansen ve diğ., 2016), mobil uygulama geliştirdiği (John ve Rani, 2015) çalışmalar görülmektedir. Ayrıca robot programlama (Ersoy, Madran ve Gülbahar 2011), e-öğrenme ortamında probleme dayalı öğrenme (Bashir ve Hoque, 2016), Alice programlama aracının kullanımı ve nörodidaktik yöntemler (Sabitzer, 2011) önerilen yaklaşımlar olarak karşımıza çıkmaktadır. Yapılan çalışmalarda tasarım odaklı araştırma, yansıtma, eşli mentör, akran değerlendirmesi gibi yöntemlerin kullanıldığı (Abad, 2008; Hansen ve diğ., 2016; John ve Rani, 2015), düz anlatım ve gösterip yaptırma gibi yöntemlerin önerilmediği (Ersoy ve diğ., 2011) görülmektedir. Sentance ve Csizmadia (2015) ise öğretmenlere derslerini gerçek hayattan problemler ve iş birlikli öğrenme üzerine yapılandırmalarını önermektedir. Aynı araştırmada programlamaya ilişkin kavramların öğretiminde belli bir programdan bahsedilmekte ve \% 13 oranında bilgisayarsız kodlama araçlarının kullanıldığını belirtmektedirler. Korkmaz, Şahin, Çakır ve Erdoğmuş'un (2019) yürüttükleri araştırmada ise öğretmen görüşlerine göre disiplinler arası çalışma ve proje yapma yöntemlerinin öne çıktığı görülmektedir.

Yaklaşımlardaki çeşitlilikle benzer şekilde, uygulamada kodlama öğretiminde kullanılabilecek birçok aracın olduğu görülmektedir. Armoni, Meerbaum-Salant ve Ben-Ari (2015), kodlama öğretiminde önerilen araçları üç 
grupta sıralamışlardır. Bunlar; kinestetik etkinlikler, görsel programlama ortamları ve robotiktir. Başka bir sınıflama ise Weinberg (2013) tarafindan bilgisayarsız kodlama etkinlikleri, blok tabanlı programlama araçları, robot programlama ve disiplinler arası uygulamalar şeklinde yapılmıştır. Kalelioğlu ve Keskinkılıç (2017) ise bu sınıflamaya metin tabanlı ortamları eklemiştir.

Bilgisayarsız kodlama projeleri birçok ülkede uygulanmaktadır. Bu etkinliklerin dünya çapında ilgi uyandırmasının sebepleri öğrencilerin ilgisini arttırması, yeni öğretim yöntemleri uygulama isteği ve bilgisayara sınırlı erişim durumunda uygulanabilecek bir yöntem olmasıdır (Bell, Alexander, Freeman ve Grimley, 2009). Nitekim ilkokul ve ortaokul öğrencileri ile yapılan bir çalışmada bu etkinliklerin ilgiyi ve motivasyonu arttırdığ gözlemlenmiştir (Nishida, Idosaka, Hofuku, Kanemune ve Kuno, 2009). Bilgisayarsız kodlama etkinlikleri ilk

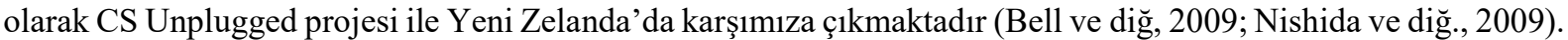
Bilgisayar kullanmadan kodlama öğretmeyi hedefleyen birçok proje arasından dikkat çeken projelerden bazıları ise csunplugged.org, tospaa.org, code.org unplugged, Keşf@ Kodlamayı Keşfediyorum ve Bilge Kunduz olarak say1labilir (KodlaManisa, 2020).

Blok tabanlı kodlama araçları öğrencinin karmaşık kod satırları arasında kaybolmasını engellemek ve programlamaya ilişkin temel kavramları daha kolay anlamasını sağlamak için tasarlanmışlardır. Blok tabanlı kodlama araçları sayesinde öğrenci sürükle bırak yöntemini kullandığı için söz dizimi hataları yapmaz. Sadece yapacağı tasarıma odaklanarak, eğlenceli bir şekilde bilgi işlemsel düşünme becerilerini geliştirebilir. Blok tabanlı kodlama araçları masaüstü, mobil veya web tabanlı uygulamalar olarak karşımıza çıkmaktadır. Blok tabanlı araçlara örnek olarak Scratch, mBlock, Alice, AppInventor, Code Org verilebilir. Blok tabanlı kodlama araçlarının özellikle K12 seviyesinde kullanışlı ve yaygın araçlar olarak karşımıza çıktığı söylenebilir.

Metin tabanlı kodlama araçları ise gerçek kod yazma deneyimini sunan araçlardır. Yapılan bazı çalışmalarda öğrencilerin blok tabanlı ortamlardan programlama dillerine geçişte sıkıntılar yaşadıkları belirtilmiştir (Meerbaum-Salant, Armoni ve Ben-Ari, 2011; Weintrop ve Wilensky, 2015). Metin tabanlı programlama dillerine geçildiğinde öğrencilerin söz dizimi kurallarına dikkat etmediği ve hata tespiti yapmakta zorlandıkları belirtilmiştir (Kandemir, 2017). Metin tabanlı kodlama araçlarına örnek olarak HackerCan, Code Combat, Code HS, CodeMonkey, Kodris verilebilir.

Günümüzde birçok ders konusunun öğretiminde kullanılan ve öğrenenlerin uygulamalı olarak program yapabildikleri robot setlerine eğitsel robotlar ismi verilmektedir (Üçgül, 2017). Eğitsel robotların kodlama öğretiminde kullanılması fikri yeni bir fikir değildir. Alanyazın incelendiğinde ilk olarak Papert'ın (1980), Piaget ve Montessori'nin çalışmalarına dayanarak ortaya koyduğu Logo Turtle karşımıza çıkmaktadır. Logo Turtle'dan sonra farklı birçok eğitsel robot üretilmiş ve kullanılmıştır. Günümüzde Türkiye'de de yaygın olarak kullanılan Lego Mindstorms, Arduino, Vex Robotik Kitleri, Makeblock, Makey Makey setleri eğitsel robotlara örnek olarak verilebilir.

Sayın ve Seferoğlu (2016) kodlama eğitimine ilişkin yaptıkları çalışma kapsamında Web of Science veri tabanında coding, coding education, learning coding, kodlama, kodlama eğitimi ve kodlama öğrenme anahtar kelimeleri ile taramalar yapmıştır. Araştırmacılar bu yolla erişilen akademik makalelerin yanı sıra çeşitli raporları araştırma soruları bağlamında incelemiştir. Araştırmacılar alanyazın taraması ve analizler sonucunda kodlama eğitimiyle ilgili olarak yapılan akademik çalışmaların çok az olduğuna işaret etmektedir. Araştırmacılar ayrıca birçok ülkenin ögretim programlarına kodlama eğitimini dâhil ettiğini veya etmek üzere hazırlıklar yaptığını ve kodlamanın 21. yüzyılda önemli bir beceri olduğunu vurgulamışlardır.

Öğretmenler öğrenme - öğretme sürecinde strateji, yöntem ve araçları uygulayan kişiler olarak önemli bir rol oynamaktadır. Kodlama eğitiminde öğretmenlere yönelik çalışmalara bakıldığında, öğretmenlerin pedagojik bilgi eksikliği ve içerik eksikliği sorunları yaşadıkları, kaygı, güven gibi bilişsel olmayan faktörlerin öğretmenlerin öğretim sürecini etkilediği görülmektedir (Kong, Li ve Kwok, 2018). Diğer taraftan Uzgur ve Aykaç (2016) bilişim teknolojileri öğretmenlerinin Bilişim Teknolojileri ve Yazılım dersine yönelik görüşlerini inceledikleri çalışmalarında, öğretmenlerin ders programına yönelik olumsuz görüş bildirdiklerini, öğrenci çalışma kitabı ve öğretmen kılavuz kitabına ihtiyaç duyduklarını, bilişim teknolojileri dersliklerinin düzenlenmesi gerektiğini ve okullar arasındaki içerik farklılıklarının ortadan kaldırılması gerektiğini bildirmişlerdir. Türker ve Pala (2018) ise yaptıkları çalışmada ortaokul öğrencilerinin, öğretmenlerinin ve velilerin kodlamaya yönelik görüşlerini incelemişlerdir. $\mathrm{Bu}$ çalışmada 13 öğretmenin kodlama öğretimine ilişkin yeterlikleri incelenmiş, 7 öğretmen kendini yeterli, 5 öğretmen kısmen yeterli, 1 öğretmen yetersiz gördüğünü belirtmiştir. Çalışmaya katılan öğretmenlerin tamamı derslerde kodlamaya yönelik içerikler sunulmasının yararlı olacağını belirtmiştir. Araştırmacılar ayrıca öğretmenlerin kodlama öğretiminde ihtiyaç duyacakları materyalleri incelemişlerdir. Öğretmenlerin \% 35.7'si derslerinde bilgisayara $(f=10)$, \% 14.3'ü robotik malzemelere $(f=4), \% 14.3$ 'ü internete $(f=4), \%$ 14.3'ü akıllı tahtaya $(f=4), \%$ 10.7'si kodlama yazılımlarına $(f=3)$ ihtiyaç olduğunu belirtmektedir. Pala ve Türker (2019) yaptıkları başka bir çalışmada 25 bilişim teknolojileri öğretmen adayının programlama 
eğitimine yönelik görüşlerini incelemiştir. Araştırmacılar bu çalışmada programlama öğretiminde öğreticinin yol göstericiliğini vurgularken Ardunia ile çalışan grupta daha fazla sorun yaşandığını belirtmişlerdir.

Görüldüğü gibi birçok ülkede kodlamaya öğretim programlarında yer verilmekle birlikte uygulamada farklı yaklaşımlar ve araçlar kullanılmaktadır. Bununla birlikte kodlama eğitiminin etkili şekilde nasıl yapılabileceğinin araştırılması ve tartışılması gerekmektedir. Kodlama öğretiminin uygulayıcıları olan öğretmenlerin, deneyimleri ile bu konuya katkıda bulunabileceği düşünülmektedir. Öğretmenlerin mesleki deneyimlerine bakıldığında meslekte geçirdikleri süre, belirli bir alan öğretiminde geçirdikleri süre ve katıldıkları eğitimler karşımıza çıkmaktadır. Bilişim teknolojileri öğretmenleri açısından bakıldığında bu durum meslekte geçirdikleri süre, kodlama öğretimi deneyimi süreleri ve kodlamaya ilişkin aldıkları eğitimler olarak söylenebilir. Dolayısıyla öğretmenlerin kodlama öğretiminde izledikleri yaklaşımlar ve kullandıkları çeşitli araçlara ilişkin görüşleri büyük önem taşımaktadır. Bu noktada öğretmenlerin kodlama öğretimindeki uygulamalarının tanımlanması ve tecrübeleri sonucunda elde ettikleri görüşlerin betimlenmesi önem arz etmektedir. Bu kapsamda araştırmada bilişim teknolojileri öğretmenlerinin kodlama öğretimine yönelik görüşlerinin incelenmesi amaçlanmış ve aşağıdaki sorulara yanıt aranmıştır:

1. Bilişim teknolojileri öğretmenlerinin kodlama öğretiminde kullandıkları

a. Araçlara ilişkin görüşleri nelerdir?

b. Öğretim yöntemlerine ilişkin görüşleri nelerdir?

c. Ölçme ve değerlendirme etkinliklerine ilişkin görüşleri nelerdir?

2. Bilişim teknolojileri öğretmenlerinin kodlama öğretiminde kullandıkları araçlar, öğretim yöntemleri ve ölçme değerlendirme yöntemleri ile

a. Mesleki deneyimleri arasındaki uyum nasıldır?

b. Kodlama öğretimi deneyimleri arasındaki uyum nasıldır?

c. Lisans sonrası aldıkları eğitimler arasındaki uyum nasıldır?

Yukarıdaki araştırma soruları kapsamında kodlama öğretiminde öğretmenler tarafından kullanılan kodlama araçlarının, öğretim etkinliklerinin ve ölçme değerlendirme araçlarının belirlenmesinin uygulayıcılara rehberlik edebileceği düşünülmektedir. Bununla birlikte kodlama öğretimi konusundaki öğretmen görüşlerinin derinlemesine incelenmesinin araştırmacılara yeni araştırma soruları belirlemede ve kodlama öğretimi programlarının geliştirilmesinde yardımcı olması beklenmektedir. Kodlama öğretiminde öğretmenlerin uygulamaları ve bu uygulamalarına ilişkin edindikleri izlenimlerinden yola çıkarak edindikleri görüşlerin incelenmesini amaçlayan bu çalışmanın kodlama öğretimine yönelik alanyazındaki tartışmalara katkı sağlaması beklenmektedir.

\section{Yöntem}

\section{Araștırmanın Deseni}

Öğretmenlerin kodlama öğretimine ilişkin görüşlerini incelemek amacıyla çalışmada nicel ve nitel araştırma yöntemlerinin birbirini izleyerek uygulandığı sıralı açımlayıcı desen kullanılmıştır (Creswell, Plano Clark, Gutmann ve Hanson, 2003). Çalışmanın bu desende gerçekleştirilmesinin nedeni öncelikle kodlama öğretimindeki mevcut durumu geniş bir örneklem grubunda sayılar ile ortaya koymaktır. Bu kapsamda kodlama öğretiminde kullanılan çeşitli araçlar, öğretim yöntemleri ve ölçme değerlendirme araçlarının betimlenmesi ve bazı değişkenler arasındaki uyumun incelenmesi hedeflenmiştir. İkinci olarak bu betimlemeden sonra öğretmenlerin kodlama öğretimine ilişkin görüşlerinin daha detaylı ele alınabilmesi için daha küçük bir katılımcı grubunun görüşlerine dayalı olarak çalışmanın nitel kısmının yapılmasına ihtiyaç duyulmuştur. Çalışmanın ilk aşaması olan hazırlık aşamasında kuramsal çerçeve ile ilgili çalışmalar yapılmıştır. Ardından nicel araştırma aşamasında anket hazırlanmış, uygulama izinleri alınmış ve nicel veriler toplanmıştır. Bilişim teknolojileri öğretmenlerinin kodlama öğretiminde kullandıkları araçlara, öğretim yöntemlerine ve ölçme değerlendirme yöntemlerine yönelik görüşlerini almak amacıyla nicel verilerin toplanmasında araştırmacılar tarafından geliştirilen anket ile kesitsel tarama yöntemi kullanılmıştır. Çalışmanın nitel araştırma aşamasında ise nicel verilerin irdelenebilmesi için katılımcılardan bazıları ile yarı-yapılandırılmış görüşmeler gerçekleştirilmiştir. Bu aşamada araştırmacılar tarafindan hazırlanan görüşme formundan yararlanılmıştır. Çalışmanın sonuç bölümünde ise nicel ve nitel veriler analiz edilerek raporlaştırılmıştır.

\section{Evren ve Örneklem}

Araştırma, Manisa ilinde 2018-2019 eğitim-öğretim döneminde ortaokullarda görev yapmakta olan bilişim teknolojileri öğretmenleriyle yürütülmüştür. Araştırma evreninin Manisa ili olarak belirlenmesinde, ilde 2014 yılından beri Kodla(Ma)nisa adıyla yürütülen proje etkili olmuştur. Valilik tarafindan desteklenen bu proje ile ilçelerde kodlama atölyeleri kurulmuş ve öğretmenlere birçok eğitim firsatının yanı sıra bilgisayar bilimleri eğitiminde kullanabilecekleri birçok aracı deneyimleme imkânı sunulmuştur. Nicel verilerin toplanması için 
geliştirilen anket Manisa ilinde ortaokullarda görev yapan yaklaşık 150 bilişim teknolojileri öğretmeninin tamamına gönderilmiş, ankete geçerli dönüş yapan 105 öğretmenden gelen veriler analiz edilmiştir. Araştırmaya katılan öğretmenlerin cinsiyet, öğrenim durumu, mesleki deneyim süreleri, kodlama öğretimi deneyim süreleri, lisans eğitimi sonrası aldıkları eğitim durumlarına ilişskin bilgiler Tablo 1'de sunulmuştur.

Tablo 1

Örneklem Grubuna İlişkin Bilgiler

\begin{tabular}{|c|c|c|c|}
\hline Değişken & Kategori & Frekans $(\mathscr{f})$ & Yüzde (\%) \\
\hline \multirow{3}{*}{ Cinsiyet } & Kadın & 48 & 45.7 \\
\hline & Erkek & 57 & 54.3 \\
\hline & Toplam & 105 & 100 \\
\hline \multirow{3}{*}{ Öğrenim Durumu } & Lisans & 96 & 91.4 \\
\hline & Yüksek Lisans & 9 & 8.6 \\
\hline & Toplam & 105 & 100 \\
\hline \multirow{4}{*}{ Mesleki Deneyim Süresi } & $1-5 \mathrm{Y} 1 \mathrm{l}$ & 29 & 27.6 \\
\hline & $6-10 Y_{11}$ & 37 & 35.2 \\
\hline & 11 Y1l ve üstü & 39 & 37.2 \\
\hline & Toplam & 105 & 100 \\
\hline \multirow{6}{*}{$\begin{array}{l}\text { Kodlama Öğretimi } \\
\text { Deneyimi Süresi }\end{array}$} & $1 Y_{11}$ & 21 & 20 \\
\hline & $2 Y_{11}$ & 22 & 21 \\
\hline & $3 Y_{11}$ & 40 & 38.1 \\
\hline & $4 Y_{11}$ & 15 & 14.3 \\
\hline & 5 Y1l ve üstü & 7 & 6.7 \\
\hline & Toplam & 105 & 100 \\
\hline \multirow{4}{*}{$\begin{array}{l}\text { Lisans Eğitimi Sonrasında } \\
\text { Kodlama Eğitimine } \\
\text { Yönelik Alınan Eğitimler }\end{array}$} & Özel kurum ve derneklerin verdiği eğitimler & 20 & 19 \\
\hline & Kodla(Ma)nisa Projesi kapsamında verilen eğitimler & 76 & 72.4 \\
\hline & MEB tarafından verilen eğitimler & 18 & 17.1 \\
\hline & Uzaktan eğitim ve çevrimiçi içerikler & 15 & 14.3 \\
\hline
\end{tabular}

Tablo 1 incelendiğinde öğretmenlerin cinsiyetlerinde önemli bir farklılık bulunmadığı görülürken, \% 91.4 oranında çok önemli bir kısmının lisans mezunu olduğu; \% 72.4'ünün 5 yıldan daha fazla mesleki deneyime sahip olduğu; $\%$ 59.1'inin 3 yıl ve üstü kodlama eğitimi deneyimine sahip olduğu görülmektedir. Ayrıca öğretmenlerden \% 80'i lisans eğitimlerini tamamladıktan sonra kodlama öğretimine yönelik çeşitli eğitimlere katıldıklarını belirtmiş ve bu eğitimler içerisinde en büyük grubu \% 72.4 ile Kodla(Ma)nisa Projesi kapsamında verilen eğitimleri alan öğretmenler oluşturmuştur.

Çalışmanın ikinci aşaması olan nitel araştırma sürecinde katılımcılar belirlenirken ölçüt örnekleme yöntemi kullanılmış ve 3 yıl ve daha fazla süredir kodlama öğretimi yapılması ölçüt olarak belirlenmiştir. Nitel araştırmanın katılımcıları, bu ölçütü karşılayan öğretmenler arasından gönüllülük esas alınarak seçilmiştir. Bu ölçütün belirlenmesinde, katılımcılara ilişkin betimsel istatistikler ile araştırmanın yapıldı̆̆ı sırada Kodla(Ma)nisa Projesinin 3. yılını doldurmuş olması nedeniyle projenin başından beri çalışmaların içerisinde yer alan öğretmenlere ulaşma hedefi etkili olmuştur. Nitel görüşmelere 9 öğretmen katılmıştır.

\section{Veri Toplama Araçları}

Nicel Veri Toplama Araçları. Araştırmanın birinci aşamasındaki verilerin toplanması için araştırmacılar tarafından Bilişim Teknolojileri Öğretmenlerinin Kodlama Öğretimine İlişkin Görüşleri Anketi geliştirilmiştir. Ankette demografik bilgiler bölümünde 7 soru, kodlama öğretimi araçları ve ölçme etkinliklerine ilişkin 3 sınıflama ile 4 sıralama olmak üzere 7 soru, kodlama öğretiminde kullanılan yöntem-teknikler ve yaklaşımlara ilişkin 5'li likert tipinde toplam 21 dereceleme sorusu bulunmaktadır. Kodlama öğretiminde kullanılan yöntem tekniklere ilişkin 11 soru Hiç etkili değildir (1), Az etkilidir (2), Kararsızım (3), Etkilidir (4) ve Çok etkilidir (5) şeklinde derecelendirilmiştir. Kodlama öğretiminde kullanılan yaklaşımlara ilişkin hazırlanan 10 soru Kesinlikle Katılmıyorum (1), Katılmıyorum (2), Kararsızım (3), Katılıyorum (4), Kesinlikle Katılıyorum (5) şeklinde derecelendirilmiştir. Anket, bilişim teknolojileri öğretmenlerine ulaşabilmek için çevrim içi ortama uygun şekilde düzenlenmiştir.

Nitel Veri Toplama Araçları. Araştırmanın ikinci aşamasında öğretmenlerin kodlama öğretiminde kullandıkları kodlama araçları, öğretim yöntemleri, ölçme değerlendirme yöntemleri hakkındaki görüşleri ile ilgili derinlemesine veri toplamak amacıyla yapılan görüşmelerde, Bilişim Teknolojileri Öğretmenlerinin Kodlama Öğretimine İlişkin Görüşleri yarı-yapılandırılmış görüşme formu kullanılmıştır. Bu görüşme formunda, öğretmenlere araştırma hakkında bilgi veren ve ses kaydı için izin istenen onam kısmından sonra demografik 
bilgiler için 3 soru, kodlama araçları, öğretim yöntemleri, ölçme değerlendirme etkinliklerine yönelik 3 soru olmak üzere toplam 6 soru ve bu sorulara ilişkin 6 sonda sorusu yer almaktadır.

\section{Geçerlik Güvenirlik Önlemleri}

Bilişim Teknolojileri Öğretmenlerinin Kodlama Öğretimine İlişkin Görüşleri Anketi hazırlama sürecinde öncelikle alanyazın taraması yapılarak benzer araştırmalar incelenmiş̧tir. Araşırıma sorularına uygun olarak açık ve kapalı uçlu sorulardan oluşan bir madde havuzu ve ardından taslak form olușturulmuștur. Taslak anket formunda 6 adet demografik bilgi, 4 adet sınıflama ve 20 adet dereceleme sorusu yer almıştır. Anketin görünüss ve kapsam geçerliğinin değerlendirilmesi için bu alanda çalışmaları bulunan 7 Bilgisayar ve Öğretim Teknolojileri Eğitimi (BÖTE) uzmanından (1 profesör, 3 doktor öğretim üyesi, 3 bilim uzmanı) görüş alınmıştır. Alınan görüşler doğrultusunda taslak anket düzenlenerek demografik bilgiler bölümünde 7 soru, kodlama öğretimi araçları ve ölçme etkinliklerine ilişkin 3 sınıflama, 4 sıralama olmak üzere 7 soru, kodlama öğretiminde kullanılan yöntem, teknikler ve yaklaşımlara ilişkin 5'li likert tipinde toplam 21 dereceli soru düzenlenmiştir.

Öğretmenlerin kodlama öğretiminde kullandıkları kodlama araçları, öğretim yöntemleri, ölçme değerlendirme yöntemleri hakkındaki görüşleri ile ilgili derinlemesine veri toplamak amacıyla yapılan görüşmeler için, Bilişim Teknolojileri Öğretmenlerinin Kodlama Öğretimine İlişkin Görüşleri yarı-yapılandırılmış görüşme formu kullanılmıştır. Görüşme formunun hazırlanması sürecinde alanyazın taraması yapılarak taslak form hazırlanmış; bu form 3 BÖTE uzmanı ve 1 dil uzmanının görüşlerine sunularak değerlendirmeleri alınmıştır. Yapılan düzenlemelerden sonra bir öğretmen ile deneme amaçlı görüş̧e yapılmış ve görüşme formuna son hali verilmiştir. Araştırmada içerik geçerliliğini sağlamak amacıyla görüşmelerden elde edilen verilerin bir BÖTE uzmanı tarafından kodlanması sağlanmıştır. Daha sonra aradaki uyuşmaya bakılarak temalar tekrar gözden geçirilmiştir. Görüşmelere ait verilerin dökümü yapıldıktan sonra görüşülen öğretmenlere gönderilerek görüşme dökümleri için onayları alınmıştır.

\section{Veri Toplama Süreci}

Araştırma desenine bağlı olarak veri toplama süreci, iki aşamada gerçekleştirilmiştir. İlk aşamada, nicel verilerin toplanması hedeflenmiştir. Bu amaçla araştırmada kullanılan anket, onam formu ile birlikte Google Form'lar kullanılarak çevrim içi ortama aktarılmıştır. Anket 2018-2019 eğitim - öğretim yılının güz döneminde öğretmenlere uygulanmıştır. Kodla(Ma)nisa projesi kapsamında, bilişim teknolojileri dersine giren ve akıllı telefona sahip tüm öğretmenler, WhatsApp gruplarına üyedirler. Bu nedenle öğretmenlere ulaşmak ve araştırmaya katılımlarını sağlayabilmek için öncelikle bu WhatsApp grupları kullanılmıștır. Ayrıca telefon numaralarına ulaşılabilen yaklaşı 65 öğretmene kısa mesaj gönderilerek ankete katılmaları istenmiştir. Ankete toplam 111 öğretmen dönüş yapmıştır.

İkinci aşamada nitel veriler toplanmıştır. Bu kapsamda öncelikle ölçüt örnekleme ile 3 yıl ve daha fazla kodlama öğretimi deneyimine sahip öğretmenler arasından telefonla ulaşlan ve görüşme yapmayı kabul eden öğretmenlere görüssmenin içeriği ile ilgili bilgi verilerek görüşme tarihi kararlaştırılmıştır. 6 öğretmen ile yüz yüze görüşülmüş, yüz yüze görüşme imkânı bulunamayan 3 öğretmenle ise telefon üzerinden görüşme yapılmıştır. Görüşmelerin tamamı araşıırmacı tarafından gerçekleştirilmiştir. Görüşmede araştırma hakkında bilgi verilmiş ve ses kaydı için izin istenmiş̧tir. Öğretmenlere öncelikle öğrenim durumları, mesleki deneyimleri ve kodlama öğretimi deneyimlerine ilişkin sorular sorulmuş, devamında kullandıkları kodlama araçları, öğretim yöntemleri ve ölçme değerlendirme yöntemleri hakkında sorular yöneltilmiştir. Görüşmeler 6-11 dakika arası sürmüştür.

\section{Veri Analizi}

Bu çalışmada Bilişim Teknolojileri Öğretmenlerinin Kodlama Öğretimine İlişkin Görüşleri Anketi’nden elde edilen kodlama araçları, öğretim yöntemleri ve ölçme değerlendirme araçlarına ilişkin nicel verilerin analizinde betimsel istatistikler kullanılmıştır. Ayrıca öğretmenlerin mesleki deneyimleri, kodlama öğretimi deneyimleri, aldıkları eğitimler ile kodlama araçları, öğretim yöntemleri ve ölçme değerlendirme etkinlikleri arasındaki ilişkinin incelenmesi için uyum analizinden yararlanılmıștı. Uyum analizinin seçiminde veri kategorilerinin çokluğu etkili olmuştur. Uyum analizi; değişkenler arasındaki ilişkilerin çok boyutlu çapraz tablolarla incelendiği durumlarda kullanılan, tanımlayıcı tipte olan bir istatistiksel tekniktir. Uyum analizi iki ya da daha çok kategorideki verilerin uyumunu inceleme olanağı sunar (Kılıç, 2016).

Araştırmanın nitel boyutunda Bilişim Teknolojileri Öğretmenlerinin Kodlama Öğretimine İlişkin Görüşleri formu ile yapılan yarı-yapılandırılmış görüşmelerde alınan ses kayıtları yazıya geçirilmiş ve elde edilen veriler ile içerik analizi yapılmıştır. İçerik analizi yapılırken birbirlerine benzeyen veriler belirli kavramlar ve temalar çerçevesinde bir araya getirilerek okuyucunun anlayacağı biçime dönüştürülmüştür (Yıldırım ve Şimşek, 2005).

\section{Araştırmacıların Rolü}

Araştırmacılardan biri kodlama öğretiminde kullanılan araçlara yönelik birçok eğitime katılmıştır ve görev yaptı̆̆ı ortaokullarda 2013 yılından bu yana kodlama öğretimi yapmaktadır. Ayrıca 2015-2017 yılları arasında kodlama 
ile ilgili bir projede ilçe koordinatörü olarak görev yapmış, eğitmen eğitimleri düzenlemiştir. Araştırmacı bu süreçte veri toplamada etkin rol almıştır. Diğer araştırmacı ise, araştırmanın tüm aşamalarında akademik danışman olarak görev almıştır. Araştırmacılar verileri toplarken ve çözümlerken alandaki deneyimlerinden yararlanmıştır. Araştırmacılar geçerlik ve güvenirlik sorunlarının önüne geçebilmek için ilgili alanyazından edindiği bilgileri sürekli göz önünde bulundurmuştur.

\section{Etik Konular}

Araştırma kapsamında veri toplama çalışmaları için Ege Üniversitesi Bilimsel Araştırma ve Yayın Etiği Kuruluna başvuru yapılmış, alınan etik kurul izin belgesi (Ek A) ile Manisa İl Milli Eğitim Müdürlüğüne başvuru yapılarak bu ildeki kurumlarda görev yapan bilişim teknolojileri öğretmenlerinden bilgilendirilmiş onamları alınarak veriler toplanmıştır.

\section{Bulgular}

\section{Bilişim Teknolojileri Öğretmenlerinin Kodlama Öğretiminde Kullandıkları Araçlara İlişkin Görüşleri}

Öğretmenlerin bilgisayarsız kodlama araçlarının, metin tabanlı kodlama araçlarının, blok tabanlı kodlama araçlarının, robotik araçların ve diğer derslerle ilişkilendirilmiş etkinliklere yönelik görüşleri Tablo 2'de sunulmuştur.

Tablo 2

Kodlama Araçlarına Yönelik Öğretmen Görüşleri

\begin{tabular}{|c|c|c|c|c|c|c|c|c|c|c|c|c|}
\hline \multirow[t]{2}{*}{ Madde } & \multicolumn{2}{|c|}{ 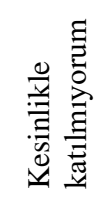 } & \multicolumn{2}{|c|}{ 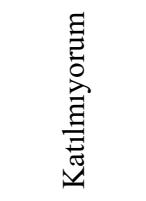 } & \multicolumn{2}{|c|}{ 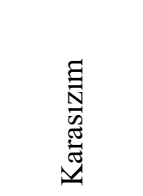 } & \multicolumn{2}{|c|}{ 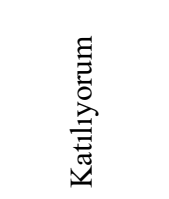 } & \multicolumn{2}{|c|}{ 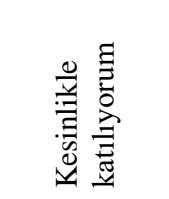 } & \multicolumn{2}{|c|}{$\frac{\Xi}{\tilde{\Xi}}$} \\
\hline & $f$ & $\%$ & $f$ & $\%$ & $f$ & $\%$ & $f$ & $\%$ & $f$ & $\%$ & $f$ & $\%$ \\
\hline Bilgisayarsız kodlama etkinlikleri & 7 & 6.7 & 12 & 11.4 & 28 & 26.7 & 44 & 41.9 & 14 & 13.3 & 105 & 100 \\
\hline Blok tabanlı araçlar & - & - & 1 & 1 & 1 & 1 & 29 & 27.6 & 74 & 70.5 & 105 & 100 \\
\hline Metin tabanlı araçlar & 1 & 1 & 10 & 9.5 & 48 & 45.7 & 28 & 26.7 & 18 & 17.1 & 105 & 100 \\
\hline Robotik araçlar & - & - & 1 & 1 & 3 & 2.9 & 31 & 29.5 & 70 & 66.7 & 105 & 100 \\
\hline Diğer derslerle ilişkilendirilmiş etkinlikler & 1 & 1 & 1 & 1 & 10 & 9.5 & 52 & 48.6 & 41 & 39 & 105 & 100 \\
\hline Toplam & 9 & 8.7 & 25 & 23.9 & 90 & 85.8 & 183 & 174.3 & 217 & 206.6 & & \\
\hline
\end{tabular}

Tablo 2 incelendiğinde öğretmenlerin ağırlıklı olarak blok tabanlı ve robotik araçları etkili buldukları görülmektedir. Öğretmenler ayrıca kodlama öğretiminde en çok code.org (\% 92.4), Scratch (\% 92.4) ve Arduino (\% 58.1) araçlarını kullandıklarını belirtmişlerdir. Öğretmenler ayrıca mBlock (\% 52.4) ve mBot (\% 46.7) araçlarını da sıklıkla kullanmaktadırlar. Öğretmenlerin bu araçları kullanma nedenlerini irdelemek üzere yapılan yarı-yapılandırılmış görüşmeler analiz edildiğinde ortaya çıkan temalar ve bu temalara ilişkin betimsel istatistikler Tablo 3'te sunulmuştur.

Tablo 3

Kodlama Araçlarının Kullanım Nedenleri

\begin{tabular}{|c|c|c|c|}
\hline & Tema & $\begin{array}{c}\text { Kodlama Sayıs } 1 \\
f\end{array}$ & $\begin{array}{c}\text { Yüzde } \\
\%\end{array}$ \\
\hline \multirow{8}{*}{ 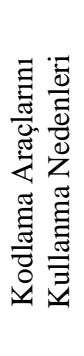 } & Düşünme Becerileri Kazandırma & 4 & 10 \\
\hline & Üretkenliği Arttırma & 3 & 7.5 \\
\hline & Kolaylık & 17 & 42.5 \\
\hline & Görsellik & 3 & 7.5 \\
\hline & Etkinliklerin Kolaydan Zora Siralanmas1 & 4 & 10 \\
\hline & Öğrenci Seviyesine Uygunluk & 6 & 15 \\
\hline & Eğlenceli Olması & 3 & 7.5 \\
\hline & Toplam & 40 & 100 \\
\hline
\end{tabular}


Tablo 3 incelendiğinde öğretmenlerin kodlama öğretiminde en çok kullandıkları araçların kullanım nedenlerine ilişkin görüşlerde kullanım kolaylığının çok önemli görüldüğü söylenebilir. Bununla birlikte kullanım nedenleri; üretkenliği arttırma, düşünme becerileri kazandırma, eğlenceli olması, görsellik, etkinliklerin kolaydan zora sıralanması ve öğrenci seviyesine uygunluk temaları ile betimlendiği bulgulanmıştır. Bu temalar eğitsel sürecin çıktıları ve eğitim-öğretim sürecine sağladığı yarar başlıkları altında toplanmaktadır.

Ĕ̌̆itsel Sürecin Çıktıları Açısından. Öğretmenlerin eğitsel sürecin çıktıları açısından nitel araştırma sürecinde bulgulanan araçları kullanma sebepleri hakkındaki görüşleri üretkenliği arttırma ve düşünme becerileri kazandırma temaları altında toplanmaktadır. Öğretmenler süreç içerisinde öğrencilerinin bir ürün ortaya koyabildikleri ve yaratıcılıklarını sergileyebildikleri araçları daha çok tercih etmektedirler. Öğretmenler bu durumu şu ifadelerle belirtmişlerdir:

...code.org ile bu algoritmayı, kodlama mantığını, blok tabanlamayı alan öğrencimiz Scratch’te artık özgün ürünler geliştirebilmeyi sağlıyor (Ö2).

...Scratch’te kendi kendine üretme becerisi kazanıyor çocuk (Ö6).

...Arduino’nun kendin yap kendin oluştur mantığı var o yüzden çocuk hem keşfediyor hem kendi kendine üretiyor (Ö9).

Yapılan görüşmeler sonucu öğretmenlerin, düşünme becerilerini öğrenciye kazandırma amaçladıkları görülmektedir. $\mathrm{Bu}$ noktada öğretmenler öğrencilerine düşünme becerilerini en iyi şekilde kazandırdığını düşündükleri araçları kullanmaktadırlar. Öğretmenlerin düşünme becerileri kazandırma teması altında toplanan ifadelerinden bazıları şöyledir:

...Çocuklara bilgi işlemsel düşünmeyi kazandırmak, düşünmeyi öğretmek amaçlı code.org bence biçilmiş kaftan (Ö3).

...Arduino kullanıyoruz. (...) [Arduino ile] problem çözme becerilerini daha da geliştirmiş oluyorlar (Ö6).

Öğretim Sürecine Sağladığı Yarar Açısından. Kodlama araçları eğitim-öğretim sürecine sağladığı yararlar açısından incelendiğinde kodlama araçlarının eğlenceli olması, kolaylığı, görselliği, içerdiği etkinliklerin kolaydan zora sıralanması ve öğrenci seviyesine uygunluğu özelliklerinin aracın seçiminde etkili olduğu bulgulanmıştır. Kullanılacak aracın kolaylığı; kavrama kolaylığı, kullanım kolaylığı, bir üst düzeye geçiş kolaylığı ve öğrenci takibinde kolaylık alt temalarıyla betimlenmektedir. Öğretmenlerin neredeyse tamamı kodlama aracını öğrencilerin kavramasını kolaylaştırması nedeniyle tercih ettiklerini söylemişlerdir. Özellikle blok tabanlı araçların kavramayı kolaylaştırdığı öğretmenler tarafından belirtilmiştir. Kavrama kolaylığı teması altında toplanan öğretmen ifadelerinden bazıları şu şekildedir:

...Blok tabanlının en önemli artısı benim açımdan çocuklara öğrenme kolaylığının sağlanması, birincil derecede. Çünkü ben daha önce meslek liselerinde de çalıştım. Orda kod tabanlı eğitim de verdim. Ben şimdi burda blok tabanlıya geçtiğim zaman öğrenmenin çok daha kolay olduğunu gördüm. (...) Blok tabanlı o anlamda çok daha kolay, öğretme açısından çok kolay (Ö7).

...O akış mantığını görsel nesnelerle çok daha kolay verebildiğimi fark ettim. O yüzden iște Small Basic tarzı uygulamaları kullanmayıp daha çok bu tarz uygulamalara yöneliyorum. (...) mBot'lar aslında çok güzel oluyor. mBot'ta işte o kapı mantığı, işte topraklama + ile - ile uğraşmadığ için çocuk, çok daha basit (Ö8).

Öğretmenlerin kodlama araçları tercihinde bir sonraki kodlama aracına geçiş kolaylığının başka bir sebep olduğu görülmüştür. Öğretmenlerin, benzer ortamlara sahip ve birbirinin devamı niteliğinde olan, yapı olarak birbirine benzeyen araçları tercih ettikleri bulgulanmıştır. Öğretmen ifadelerinden bazıları şu şekildedir:

...yukarıdan aşağıya doğru akışı olanları daha çok tercih ediyorum. Mesela Lego'dan ziyade MakeBlock gibi olanları, sürükle bırak ikisi de biliyorsunuz. Onları daha çok tercih ediyorum. Çünkü algoritmayı, akış şeması şeklinde, o şekilde öğreniyor çocuk. Onu sonrasında metin tabanl olarak dönüştürmesi de daha yatkın oluyor (Ö1).

...mBot özellikle başlangıç için çok uygun çocuklarımız için. Çünkü Scratch'in devamı gibi mBlock. (...) Scratch’te ekranda yaptırdıkları şeyleri robota yaptırmaya başlıyorlar dediğim gibi devam niteliğinde olduğu için kullanımında zorluk çekmiyorlar (Ö5).

Kullanılacak aracın içerdiği öğrenme etkinliklerinde, kavramların kolaydan zora sıralanması öğretmenler tarafından değerli bulunmaktadır ve bir kullanma sebebi olarak değerlendirilmiştir: 
...Bir de çok gelişmiş 1111 problemleri basitten zora doğru anlatıyor ve bölüm bölüm her konu eee her kod eee her teknik 111 ayrıntılarıyla basamaklar şeklinde basitten zora doğru etkinliklerle gittiği için code.org'tan başliyorum (Ö6).

Kullanılacak araçlarının kullanımlarının kolay olması öğrencinin öğrenilecek kavramlara daha iyi odaklanmasını sağlayabilir. Görüşmenin gerçekleştirildiği öğretmenlerin araç seçiminde kullanım kolaylığını göz önünde bulundurduğu değerlendirilmiştir:

...mBot'u sevme sebebim elektronik bilgisini bilmeyen bir çocuk kodlamanın somutlaştırılmasını sağlayacak bir sistem ile karşılaşıyor mBot sayesinde. Sadece RJ25 kabloları dediğimiz kabloları takarak istediği görevi çok rahat bir şekilde yaptırabiliyor (Ö2).

Ayrıca öğretmenlerin kodlama araçlarını seçerken öğrenci takibini kolaylıkla yapabildikleri araçlara yöneldikleri bulgulanmıştır:

...Ayrıca çocuğun ilerlemesini takip edebilmek, bireysel çalışmalarını teşvik edebilmek amacıya code.org'u özellikle tercih ediyorum (Ö2).

Kodlama aracının öğrenci seviyesine uygunluğu öğretmenlerin tamamına yakını tarafından kullanım sebebi olarak belirtilmiştir:

...Seviyeye göre değişiyor tabii ki. İlkokul öğrencileri için blok tabanlı, ilkokul ve ortaokul öğrencilerinin birinci bölümü için blok tabanlı programlama araçları kullanıyorum. Daha büyük yaşlarda metin tabanlı programlama araçlarını 111 kullanmaya başlıyorum (Ö1).

...öğrenme aşamasında sürükle bırak mantığı önemli. Ama ileriki seviyelerde bir sonraki üst seviyelere çıktığı zaman sürükle bırak artık yorucu olmaya başlıyor. Yorucudan ziyade yazması zorlaşıyor. Ekranda alan kalmıyor. Bloklar iç içe giriyor. Eee ekranda bir sürü blok olduğu için bu sefer karışıklık daha fazla oluyor. Bir üst seviyelerde Arduino'nun üst seviyelerinde artık metin tabanlı kod yazmayı hedefliyoruz, geçiriyoruz da (Ö6).

Yaşa göre düzenlenmiş renkler ve grafikler eğitim-öğretim sürecinde öğrencinin ilgisini canlı tutarak, süreci olumlu etkileyebilir. Öğretmenler de kullanılacak aracın seçiminde başka bir sebep olarak görselliğin etkili olduğunu belirtmişlerdir:

...Görsel olarak çok güzel (...) Gerek görselleri, gerek programlama kısmının çocuklar için daha uygun olması sebebiyle buna imkan sağlıyor o yüzden (Ö5).

...Renkli olduğu için öğrencilerin dikkatini çok kolay toplayabiliyoruz. Oyun formatında öğretmek kolay oluyor. Diğer 111 kod tabanlı ile başladığımız zaman çocuk onun ne olduğunu anlayıncaya kadar çok uzun bir süre geçiyor ama bunda en azından diyorsun ki işte karar mekanizması mavidir, şartlar sarıdır, o şekilde kendini rahatlatıyor. Bizim o kavramı oturtmamız daha kolay oluyor (Ö7).

Öğrenme öğretme sürecinde daha olumlu bir sınıf ortamı oluşturulabilmesi için dersin eğlenceli etkinliklerle desteklenmesi faydalı olabilir. Öğretmen görüşleri incelendiğinde, öğretmenlerin kullandıkları aracın eğlenceli olmasını olumlu olarak değerlendirdikleri görülmüştür:

...İstediklerini yaptırabildikleri robotu görünce de keyiflerine keyif katıyorlar. Hoşlarına gidiyor, mutlu oluyorlar görünce. (...) İnteraktif hikayeler kurabiliyorsunuz. Bir hikaye oluşturmak da çocuk için çok eğlenceli olduğunu fark ettim ben. Daha çok böyle hikaye, küçük böyle 111 masallar şekilde... çok eğleniyorlar. (...) Karekterleri çok eğlenceli. Çocuklar, o karakterler, çocukların çok hoşuna gidiyor. (...) mBot'la aynı amaçla, Arduino'da da fiziksel olarak ortaya çıkan sonucu görmek çocukları mutlu ediyor (Ö5).

Ayrıca bir öğretmen tarafından, zaman yönetimi vurgusu yapılmış ve tasarım sürecinin ders saatleri içerisinde tamamlanabilmesinin gerekliliği vurgulanmıştır:

...Ortaokul düzeyinde mBot, Arduinoyu Lego'ya tercih etme sebebim ise Lego ile tasarım aşaması çok uzun sürüyor ve her derste bir tasarım yaptırmanız mümkün olmuyor (Ö2).

Bilişim Teknolojileri Öğretmenlerinin Kodlama Öğretiminde Kullandıkları Öğretim Yöntemlerine İlişkin Görüşleri

Bilişim teknolojileri öğretmenlerinin kodlama öğretiminde kullandıkları yöntemlere ilişkin görüşleri Tablo 4'te sunulmuştur. 
Tablo 4

Kodlama Öğretiminde Kullanılan Öğretim Yöntemlerine Ilişkin Öğretmen Görüşleri

\begin{tabular}{lccccccccccc}
\hline & \multicolumn{2}{c}{ Hiç etkili değildir } & \multicolumn{2}{c}{ Az etkilidir } & \multicolumn{2}{c}{ Fikrim yok } & \multicolumn{2}{c}{ Etkilidir } & \multicolumn{2}{c}{ Çok etkilidir } \\
\cline { 2 - 8 } Yöntem & $\boldsymbol{f}$ & $\%$ & $\boldsymbol{f}$ & $\%$ & $\boldsymbol{f}$ & $\%$ & $\boldsymbol{f}$ & $\%$ & $\boldsymbol{f}$ & $\%$ \\
\hline Anlatım yöntemi & 1 & 1 & 35 & 33.3 & 7 & 6.7 & 56 & 53.3 & 6 & 5.7 \\
Gösterip yaptırma yöntemi & 1 & 1 & 1 & 1 & 1 & 1 & 31 & 29.5 & 71 & 67.6 \\
Drama yöntemi & 3 & 2.9 & 4 & 3.8 & 27 & 25.7 & 44 & 41.9 & 27 & 25.7 \\
Eşli mentör yöntemi & 1 & 1 & 3 & 2.9 & 4 & 3.8 & 58 & 55.2 & 38 & 36.2 \\
Proje tabanlı öğrenme yöntemi & 1 & 1 & - & - & 8 & 7.6 & 32 & 30.5 & 64 & 61 \\
Oyun tabanlı öğrenme yöntemi & 1 & 1 & - & - & 3 & 2.9 & 30 & 28.6 & 71 & 67.6 \\
Dene, kurcala, öğren yöntemi & 2 & 1.9 & 2 & 1.9 & 8 & 7.6 & 31 & 29.5 & 61 & 58.1 \\
\hline
\end{tabular}

Öğretmenlerin diğer öğretim yöntemleriyle karşılaştırıldığında oyun tabanlı öğrenme, gösterip yaptırma ve oyun yazma yöntem ve etkinlikleri hakkında daha olumlu görüş bildirdikleri görülmektedir. En az etkili buldukları yöntem ise anlatım yöntemi olmuştur. Öğretmenlerin bu öğretim yöntemlerini kullanma nedenlerini irdelemek üzere yapılan yarı-yapılandırılmış görüşmeler analiz edildiğinde ortaya çıkan temalar öğrenmeyi zenginleştirme \% $50(f=50)$; kalıcı öğrenme sağlama \% 37,5 $(f=6)$; çevresel koşullar \% 12,5 $(f=2)$ olarak bulgulanmıştır. Öğretmenlerin büyük çoğunluğu, öğrenme ortamını zenginleştirdiğini düşündükleri öğretim yöntemlerini kullanmaktadırlar. Buna ilişkin bir öğretmenin ifadesi şu şekildedir:

...Biz sadece öğretmenler olarak herhalde yöntem ve tekniklerimizde hala eski yöntem ve tekniklerle bu işi sürdürmeye çalışıyoruz. En büyük eksikliğimiz olarak bunu görüyorum. Nedir işte hala "göster yap"la, hala işte not almakla, not yazdırmakla ya da işte çocuğun pasif olduğu öğretmenin daha çok aktif olduğu eğitim ortamlarıyla bu işi yürütmeye çalışıyoruz. Bu da çok büyük dezavantaj diye düşünüyorum. Çocuğa bizim planladığımız sadece bizim aklımızdakinin aktarılması, işte çocuğa keşfetme çocuğun yeni bir şey oluşturmasına firsat verildiği ortamlar, daha özgür çalışmaların yapıldı̆̆ı ortamlar oluşturulması gerektiğine inanıyorum (Ö1).

Öğretmenlerin ikinci olarak kalıcı öğrenmeyi destekleyen öğretim yöntemlerine öncelik verdikleri görülmüştür. Buna ilişkin öğretmen ifadelerinden bazılarına aşağıda yer verilmiştir:

...Özellikle günlük hayatlarından problemler verdiğimiz zaman içselleştirmeleri daha kolay oluyor ve keşfettikleri şeyleri daha kalıcı bilgiler sağladığını, daha kalıcı bir öğrenme sağladığını düşünüyoruz. O yüzden keşfetmeyle başlayıp, 111 işte çeşitli problem durumlarını karşılarına getirip onları çözmeleri için yardımcı oluyoruz (Ö1).

...Sebebi artık hani çocuklar, bir problemi verip ee öğretmen merkezliden çıkıp onların kendilerinin keşfetmesi, deneme yanılma yoluyla bulması ee ve sonuca baktığınızda da gerçekten kalıcı öğrenmenin daha 1111 yoğun olmas1 sebebiyle (Ö2).

...Önceliğim keşfederek, çocuğun ihtiyaç duyarak öğrenimi. Konu anlatımı yapmıyorum ben. O sohbet ederken diyorum şunu yapın. "Nasıl yapacağız hocam? Demek ki şuna ihtiyacımız var diyorlar. Sonra kendileri bulunca onu bir daha unutmuyorlar yani (Ö7).

Öğretmenler, her ne kadar öğrenme ortamını zenginleştirmeyi ve öğrenmenin kalıcılığını önemsiyor olsalar da, öğretim yöntemini seçerken fiziksel koşullar nedeniyle farklı tercihlere yönelebilmektedirler. Bu bağlamda öğretmenlerin kullanacakları öğretim yöntemine karar verirken çevresel koşulları göz önünde bulundurdukları görülmektedir:

...Ona biraz hmmm okulun şartlarından dolayı diyeyim özel sebep olarak. Belki daha farklı yöntemler de deneyebilirdim ama eee ders saatimizin 2 saat olması, 111 sınıfların yoğunluğu, bilgisayar sayılarımızın malum sayıda olmasından dolayı biraz zorunlu olarak da bunu tercih ediyorum. Belki kendilerinin, tamamen kendilerinin çözmesini de sağlayabilirdim. Bu metodu da kullanabilirdim. Fakat bu şartlar altında bu pek uygun olacak bir metot değil (Ö5).

\section{Bilişim Teknolojileri Öğretmenlerinin Kodlama Öğretiminde Kullandıkları Ölçme ve Değerlendirme Etkinliklerine İlişkin Görüşleri}

Bilişim teknolojileri öğretmenlerinin kodlama öğretiminde kullandıkları ölçme ve değerlendirme araçları Tablo 5 'te verilmiştir. 
Tablo 5

Kodlama Öğretiminde Kullanılan Ölçme ve Değerlendirme Araçları

\begin{tabular}{lcc}
\hline Ölçme Aracı & Frekans & Yüzde \\
$\%$ & $f$ & 72.4 \\
\hline Uygulama sınavları & $f$ & 69.5 \\
Proje & 76 & 39 \\
Öğrenci ürün dosyası & 73 & 31.4 \\
Çoktan seçmeli testler & 41 & 23.8 \\
Gözlem & 33 & 11.4 \\
Açık uçlu sorular içeren sınavlar & 25 & 10.5 \\
Sergi & 12 & 5.7 \\
Doğru yanlış testleri & 11 & 4.8 \\
Öz değerlendirme formları & 6 & 4.8 \\
Sözlü sunum & 5 & 3.8 \\
Akran değerlendirme formları & 5 & 1.9 \\
Sözlü sınavlar & 4 & \\
\hline
\end{tabular}

Öğretmenlerin ölçme ve değerlendirme araçları ile ilgili görüşleri incelendiğinde, en çok kullanılan araçlar sırasıyla uygulama sınavları, proje ve öğrenci ürün dosyası olmuştur. Öğretmenlerin en az sözlü sınavları kullandıkları görülmektedir. Öğretmenlerin ölçme ve değerlendirme araçlarına karar vermelerine ilişkin görüşleri incelendiğinde süreci değerlendirme olanağı (\% 50) ve öz değerlendirme olanağı $(\% 50)$ temalarında kodlandığı bulgulanmıştır. Ölçme araçlarının tüm süreci değerlendirme imkânı sunması, öğrencilerden alınan anlık değerlendirme sonuçlarına göre çok daha doğru sonuçlar verebilir. Öğretmenlerin de süreci değerlendirebildikleri ölçme ve değerlendirme araçlarını tercih ettikleri görülmektedir. Buna ilişkin öğretmen ifadeleri şu şekildedir:

...Genellikle ürün dosyası benim için önemli, çünkü süreç önemli benim için, sonuç değil. Süreç boyunca da ürün dosyasını da takip edip ona göre bir değerlendirme yapmak istiyorum.”(Görüşme1)

"Ürün dosyasında da aynı şey, bütün seneyi bir anlamda değerlendirmiş oluyorsunuz. Bütün yaptığı çalışmaları görebiliyorsunuz ve çok güzel bir veri olmuş oluyor elinizin altında (Ö8).

Öğrencinin öğrenme sürecinde kendini değerlendirerek bulunduğu noktanın farkında olması öğrencinin kendini geliştirmek için güdülenmesine yardımcı olabilir. Öğretmenlerin ölçme ve değerlendirme aracına karar verirken öğrencinin öz değerlendirme yapabilmesini önemsedikleri görülmektedir:

...Kendini çocuğun öz değerlendirmesi 11 çok önemli. Bu da zaten gerçek yaşama bir sonuç getiriyor. Onların 1111 gerçekten bir şeyler öğrenip öğrenmediğini farkında olması da çok önemli (Ö1).

...Ürün dosya, dijital portfolyo. Bunları saklıyoruz bilgisayarda ve en son not verme amacı ile olmasa da çocuk kendi gelişimini görebiliyor. Bunları kullanıyoruz (Ö4).

Ayrıca Ö8, ölçme ve değerlendirme araçlarında en önemli tercih sebebinin ölçmenin güvenirliğini sağlaması olduğunu belirtmiş̧tir:

...Tek tek sorduğum için çocuğun adım adım yapıp yapamadığı görüyorum. Tabi orda çocuk problemle karşı karşıya kaldığı için herhangi bir şekilde ölçmeyi tehlikeye atacak bir durumla da karşılaşmıyorum. Yani arkadaşına bakıp o nasıl yapıyor. Yani bu testteki bir şık değil, arkadaşım "A" yapmış o zaman A şekilde değil. Birine bakma ihtiyacı bile hissetse bakacak, nasıl yaptığını gözlemleyecek, iki dakikalık bir süreç. O iki dakikalık süreçte her halde öğretmen fark eder. Hem güvenilir bu anlamda, en önemli tercih etmemin sebebi bu: güvenilir (Ö8).

Ölçme aracında geçerlik ve güvenirliğin yanı sıra kullanışlılık da önemli bir özellik olarak karşımıza çıkmaktadır. Ölçme aracının türüne karar verirken kullanışlılığını göz önünde bulundurduğunu söyleyen Ö5, buna ilişkin görüşlerini şu şekilde ifade etmiştir:

...Şube sayılarından ve mevcut imkanlardan dolayı diyeceğim öncelikle, dediğim gibi kalabalık olmasından dolayı ben ölçme değerlendirme olarak sınav uygulaması yapıyorum. (...) Uygulama yaptırmak isterdim. Bilgisayarlarında oturup, hadi şunu yap bakalım deyip canlı canlı önünde butonlar işte eee bloklar. Hepsi. Bu hangi başlık altındaydı diye düşünmeden oradan deneye deneye bularaktan [bularak] çocuğun yapmasını isterdim. Uygulama metodunun ölçme değerlendirme açısından daha verimli olacağını düşünüyorum fakat sınıflarımızın mevcudu, bilgisayar sayılarımızdan dolayı sınav metodunu kullanıyorum, çoktan seçmeli (Ö5). 
Kodlama Öğretiminde Kullanılan Araçlar, Öğretim Yöntemleri ve Ölçme Değerlendirme Etkinlikleri ile Çeşitli Değişkenler Arasındaki Uyumun İncelenmesi

Araştırmada kodlama öğretiminde kullanılan araçlar, öğretim yöntemleri, ölçme değerlendirme etkinlikleri ile mesleki deneyim, kodlama öğretimi deneyimi ve lisans sonrası eğitimler arasındaki ilişki uyum analizi ile incelenmiştir. Uyum analizi, $\mathrm{r}$ x c tipinde çapraz tablo haline getirilmiş $\mathrm{X}$ ve $\mathrm{Y}$ değişkenlerinin ya da $\mathrm{r} \times \mathrm{c} \mathrm{x} \mathrm{m}$ biçiminde çok boyutlu tablo haline getirilmiş $\mathrm{X}, \mathrm{Y}$ ve $\mathrm{Z}$ değişkenlerinin kategorilerine ait frekans tipindeki veriler ile yapılır. Bu analiz çapraz tabloların sıra ve sütunlarının birlikte değişimini, değişkenler arasındaki uyumu ortaya koymak ve bunu grafiksel olarak göstermek için kullanılır (Kılıç, 2016).

Uyum analizi sonucunda elde edilen boyutlara ve genel değişim (inertia) değerlerine ilişkin veriler incelendiğinde Ki-Kare testi sonucunda toplam inertianın sıfırdan anlamlı bir şekilde farklı olup olmadığına bakılır. Yapılan analizler sonucunda yalnızca kodlama öğretimi deneyimi ile kullanılan ölçme ve değerlendirme araçları arasında anlamlı bir ilişki olduğu görülmüştür $\left(x^{2}(4)=136.429, p<.05\right)$. Buna göre satır ve sütun değişkenleri arasında bir ilişki olduğu ve satır ve sütunların birbirinden bağımsız olmadığı söylenebilir. Toplam inertia 4 boyutta açıklanmakta ve açıklanan inertianın \% 85.6'lık kısmı birinci boyut, \% 12'lik kısmı ikinci boyut tarafından açılanmaktadır. Ayrıca inertianın çok küçük bir kısmının üçüncü boyut $(\% 1.7)$ ve dördüncü boyut $(\% 0.7)$ tarafından açıklandığı görülmüştür. Tablo 6'da satır ve sütun değişkenlerinin boyutlara katkısı ve açıkladıkları inertia değerleri verilmiştir.

Tablo 6

Boyut Sayısı ve Açıklanan Inertia Değerleri

\begin{tabular}{|c|c|c|c|c|c|c|c|c|c|c|}
\hline & & & \multicolumn{2}{|c|}{ Boyut Puanları } & \multirow{3}{*}{$\begin{array}{l}\text { Genel } \\
\text { Değişim }\end{array}$} & \multicolumn{5}{|c|}{ Katk1 } \\
\hline & \multirow[t]{2}{*}{ Değiş̧ken } & \multirow{2}{*}{$\begin{array}{l}\text { Ağırlık } \\
\text { Payı }\end{array}$} & 1 & \multirow[t]{2}{*}{2} & & \multicolumn{2}{|c|}{$\begin{array}{l}\text { Boyutların } \\
\text { noktalara }\end{array}$} & \multicolumn{2}{|c|}{$\begin{array}{l}\text { Noktaların } \\
\text { boyutlara }\end{array}$} & \multirow{2}{*}{ Toplam } \\
\hline & & & & & & 1 & 2 & 1 & 2 & \\
\hline \multirow{8}{*}{ 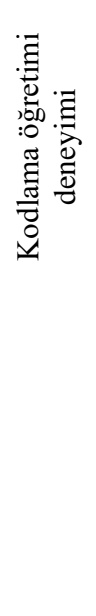 } & 1 Yil & .219 & .888 & -.157 & .117 & .262 & .022 & .974 & .011 & .985 \\
\hline & 2 Yil & .193 & -.817 & -.016 & .090 & .196 & .000 & .941 & .000 & .941 \\
\hline & 3 Yil & .353 & -.690 & -.056 & .114 & .255 & .005 & .968 & .002 & .971 \\
\hline & 4 Yil & .156 & .772 & .940 & .096 & .141 & .558 & .640 & .355 & .995 \\
\hline & 5 Y1l ve üstü & .078 & 1.107 & -1.145 & .090 & .145 & .415 & .704 & .282 & .986 \\
\hline & $\begin{array}{l}\text { Doğru yanlış } \\
\text { testleri }\end{array}$ & .033 & -.865 & .275 & .018 & .038 & .010 & .934 & .035 & .970 \\
\hline & $\begin{array}{l}\text { Çoktan seçmeli } \\
\text { testler }\end{array}$ & .052 & .954 & 1.041 & .046 & .072 & .228 & .680 & .303 & .984 \\
\hline & $\begin{array}{l}\text { Açık uçlu sorular } \\
\text { içeren yazılı } \\
\text { sinavlar }\end{array}$ & .193 & -.732 & -.141 & .071 & .157 & .016 & .963 & .013 & .976 \\
\hline \multirow{9}{*}{ 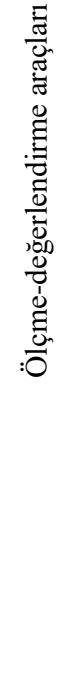 } & Sözlü sınavlar & .015 & -1.144 & -.146 & .015 & .030 & .001 & .861 & .005 & .866 \\
\hline & Uygulama sinavi & .197 & .419 & .009 & .023 & .053 & .000 & .998 & .000 & .998 \\
\hline & $\begin{array}{l}\text { Öz değerlendirme } \\
\text { formları }\end{array}$ & .019 & .456 & -1.273 & .013 & .006 & .122 & .197 & .576 & .773 \\
\hline & $\begin{array}{l}\text { Öğrenci ürün } \\
\text { dosyas1 }\end{array}$ & .100 & .158 & .111 & .002 & .004 & .005 & .670 & .124 & .794 \\
\hline & $\begin{array}{l}\text { Akran } \\
\text { değerlendirme } \\
\text { formları }\end{array}$ & .022 & -1.112 & -.173 & .019 & .042 & .003 & .977 & .009 & .986 \\
\hline & Gözlem & .175 & -.713 & .039 & .060 & .135 & .001 & .975 & .001 & .976 \\
\hline & Sözlü sunum & .041 & -.698 & .161 & .015 & .030 & .004 & .893 & .018 & .911 \\
\hline & Proje & .126 & 1.344 & .226 & .152 & .347 & .026 & .987 & .010 & .997 \\
\hline & Sergi & .026 & 1.490 & -2.351 & .074 & .088 & .583 & .515 & .480 & .995 \\
\hline
\end{tabular}


Uyum analizinde, noktaların boyutlara katkısı herhangi bir boyuttaki inertianın o nokta tarafından açıklama yüzdesi olarak yorumlanır. İlgili boyutta daha önemli olan noktaların katkısı daha büyüktür. Boyutların noktalara katkısı ise, her bir noktanın her bir boyut tarafından ne kadar iyi açıklandığını göstermektedir. Kodlama öğretimi deneyimi değişkenine ait veriler incelendiğinde birinci boyutta en çok katkıyı 1 yıllık kodlama öğretimi deneyimine sahip öğretmenlerin yaptıkları, ikinci boyutta ise 4 yıllık deneyime sahip öğretmenlerin yaptıkları söylenebilir. Ölçme ve değerlendirme araçlarında ise birinci boyutta en yüksek katkıyı sergi, proje ve çoktan seçmeli testlerin yaptığı, ikinci boyutta ise çoktan seçmeli testlerin, proje ve öğrenci ürün dosyalarının yaptığı görülmektedir. Inertia değerleri incelendiğinde ise kodlama öğretimi deneyimi değişkeninde toplam inertianın büyük kısmını 3 yıllık kodlama öğretimi deneyimi kategorisi açıklarken, ölçme-değerlendirme değişkeninden inertianın büyük kısmını proje kategorisi açıklamaktadır. Uyum analizi sonucunda elde edilen satır ve sütun noktalarının düzlemde birlikte gösterimi Şekil 1'de verilmiştir.

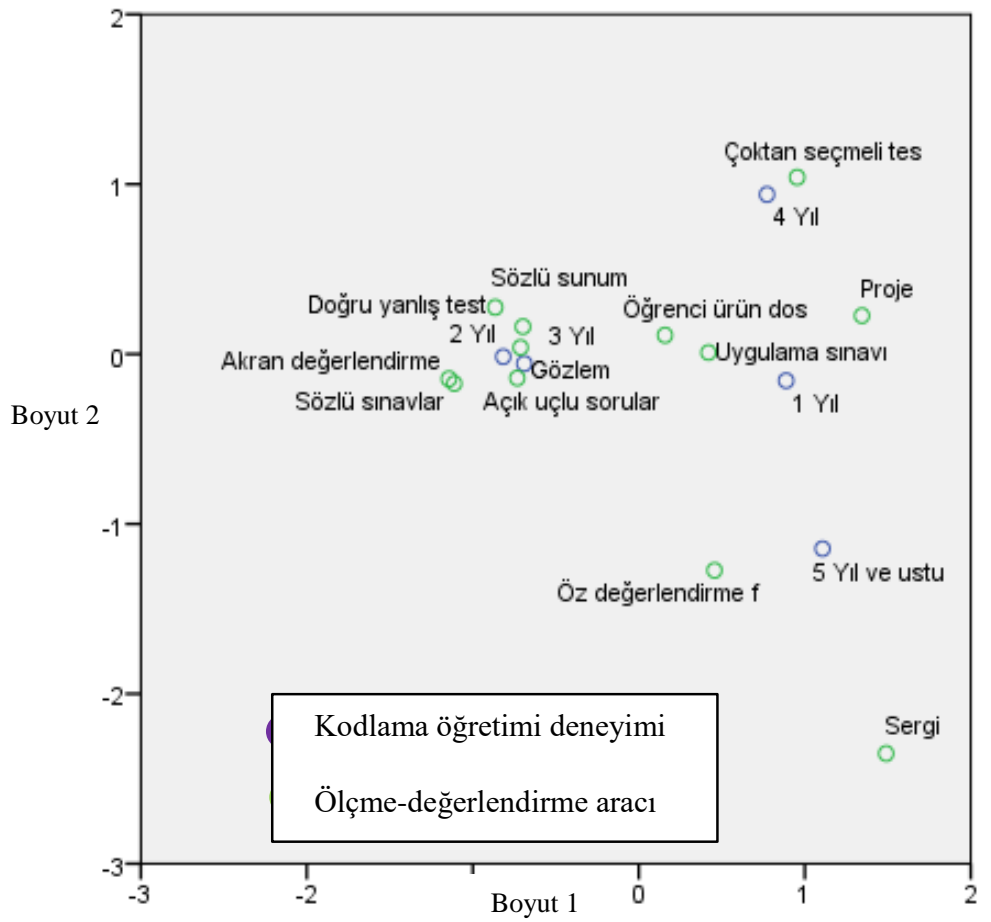

Şekil 1. Satır ve sütun noktalarının düzlemde birlikte gösterimi

Şekil 1 incelendiğinde 4 y1llık kodlama öğretimi deneyimine sahip öğretmenlerin ölçme ve değerlendirme aracı olarak çoktan seçmeli testleri daha çok kullandıkları, 5 yıl ve üstü kodlama öğretimi deneyimine sahip öğretmenlerin diğer öğretmenlere göre öz değerlendirme formlarını ve sergiyi daha çok kullandıkları söylenebilir. Diğer taraftan öğretmenlerin kodlama öğretiminde ilk yılda uygulama sınavını daha çok kullandıkları görülmektedir.

\section{Sonuç ve Tartışma}

Bu araştırmada Manisa ilinde ortaokullarda görev yapan bilişim teknolojileri öğretmenlerinin bilgisayar bilimleri eğitiminde kullandıkları araçlara, öğretim yöntemlerine ve ölçme değerlendirme yöntemlerine ilişkin görüşleri incelenmiştir. Kodlama öğretiminde kullanılabilecek birçok araç, öğretim yöntemi ve ölçme değerlendirme yöntemi bulunmaktadır. Weinberg (2013), Armoni ve diğerleri (2015) ve Kalelioğlu ve Keskinkılıç'ın (2017) yaptığı sınıflandırmalar incelendiğinde, bilgisayar bilimleri eğitiminde kullanılabilecek araçların; bilgisayarsız kodlama etkinlikleri, blok tabanlı araçlar, metin tabanlı araçlar ve robotik araçlar olarak gruplandırılabileceği görülmektedir. $\mathrm{Bu}$ araştırmada öğretmenlerin blok tabanlı kodlama araçlarını ve robotik kodlama araçlarını daha etkili buldukları görülmüştür. Nitekim alanyazın incelediğinde kavram yanılgılarını en aza indirmesi nedeniyle K12 seviyesinde blok tabanlı programlamanın önerildiği görülmektedir (Mladenović, Boljat ve Žanko, 2018). Öğretmenler blok tabanlı ve robotik kodlama araçları arasında en çok code.org, Scratch ve Arduino araçlarını kullanmaktadırlar. Kodlama ile düşünme becerilerinin öğrenciye kazandırılması mümkündür (Chao, 2016; GarcíaPeñalvo, Reimann, Tuul, Rees ve Jormanainen, 2016; Kalelioğlu ve Gülbahar, 2014; Kukul ve Gökçearslan, 2014; Fessakis ve diğ., 2013; Clements ve Gullo; 1984). Öğretmenlerin bu araçları kullanma sebepleri irdelendiğinde ise öğrencilerine düşünme becerileri kazandırmayı ve üretkenliği arttırmayı amaçladıkları görülmüştür. Ayrıca öğretmenler bu araçları kolaylığı, görselliği, öğrenci seviyesine uygunluğu ve eğlenceli olması nedeniyle de 
kullanmaktadırlar. Diğer taraftan bu araçların birçok eğitim kurumunda yaygın olarak kullanılmasının ve alınan eğitimlerde bu araçlara yönelik uygulamalar yapılmasının öğretmenlerin tercihlerinde etkili olabileceği düşünülmektedir.

Alanyazında bilgisayar bilimleri eğitiminde kullanılan öğretim yöntemleri değerlendirildiğinde, oyun programlama (Fokides, 2017; Jenson ve Droumeva, 2016), dijital hikâye yazma (Hansen ve diğ., 2016), mobil uygulama geliştirme (John ve Rani, 2015) gibi uygulamaların yapıldığı görülmektedir. Alanyazındaki çalışmalarda ayrıca, ögretmenlerin kavramların öğretiminde oyun programlama yöntemini faydalı buldukları ve gösterip yaptırma yöntemini sıklıkla kullandıkları belirtilmiştir (Akbıyık ve Seferoğlu, 2012; Nouri, Norén ve Skog, 2018). $\mathrm{Bu}$ araştırmaya katılan öğretmenlerin alanyazına paralel olarak en çok gösterip yaptırma, oyun tabanlı programlama, oyun yazma ve keşfetme yöntemlerini kullandığı tespit edilmiştir. Araştırmanın nitel bulgularına göre; öğretmenler bu öğretim yöntemlerini öğrenme ortamını zenginleştirmek ve kalıcı öğrenme sağlamak için tercih etmektedirler. Ayrıca çevresel koşulların öğretmenlerin seçimlerinde etkili olduğu görülmüş, sınıf mevcudunun fazla olduğu ve yeterli araç gerecin bulunmadığı durumlarda ögretmenlerin ideal buldukları yöntemlerin dışındaki yöntemlere yöneldiği bulgulanmıştır. Bu sonuçların kodlama öğretiminde kullanılan araçlar ile uyumlu olduğu görülmektedir. Öğretmenlerin kodlama öğretiminde daha çok blog tabanlı ve robotik araçları tercih etmeleri nedeniyle öğretim etkinliklerinde oyun tabanlı ve keşfe dayalı etkinliklerden yararlandıkları düşünülmektedir. Bu kapsamda Uzgur ve Aykaç’ın (2016) çalışmalarındaki bulgulara paralel olarak öğrenci çalışma kitapları ve öğretmen kılavuz kitaplarının hazırlanması ve güncel tutulmasının önemli olduğu düşünülmektedir.

Araştırmaya katılan öğretmenler, ölçme değerlendirme araçları olarak en çok uygulama sınavı, proje ve öğrenci ürün dosyasını kullanmaktadır. Nitel bulgulara göre öğretmenlerin, ölçme değerlendirme aracının süreci değerlendirme ve öz değerlendirme imkânı sunmasını önemsedikleri görülmektedir. Alanyazında, bilgisayar bilimleri eğitiminde süreci değerlendirmeye yönelik olarak kullanılan biçimlendirici değerlendirmeye vurgu yapılmaktadır (Grover, 2014, Kong, 2016; Kotini ve Tzelepi, 2015).

Araştırma kapsamında öğretmenlerin mesleki deneyim süreleri, kodlama öğretimindeki mesleki deneyim süreleri, kodlama öğretimine ilişkin alınan eğitim değişkenleri ile kodlama öğretiminde kullanılan araçlar, öğretim yöntemleri ve ölçme değerlendirme araçları arasındaki ilişki incelenmiştir. Uyum analizi sonucunda yalnızca kodlama öğretimindeki mesleki deneyim süresi ile kullanılan ölçme değerlendirme araçları arasındaki ilişki anlamlı bulunmuştur. 5 yıl ve daha uzun süredir kodlama eğitimi veren öğretmenlerin öz değerlendirmeyi daha çok kullandıkları görülmüştür. Bu noktada öğretmenlerin deneyimleri arttıkça öğrencinin öğrenme sürecinde bulunduğu noktayı fark edebilmesini önemsedikleri söylenebilir. Yeni’ye (2017) göre; öğrencinin öğrenme sürecini denetlemekten sorumlu olmasını sağladığı için, öğrencilerin Scratch gibi araçlarla ortaya koydukları ürünleri öz değerlendirme formları ile değerlendirmeleri öğrenme sürecinin önemli bir parçasını oluşturmaktadır. Bilgisayar bilimleri eğitiminin temelde problem çözme becerilerini desteklemesi nedeniyle kodlama öğretiminde sürece dayalı değerlendirmenin ve ölçme araçlarının kullanılmasının önemli olduğu düşünülmektedir. Benzer şekilde öğretmenler için yapılacak kodlama öğretiminde kullanılabilecek farklı öğretim yöntemleri, kodlama araçlarının kullanımı ve ölçme değerlendirme araçlarına dönük yapılacak eğitimlerin Kong, Li ve Kwok'un (2018) belirttiği pedagojik bilgi eksikliğini ortadan kaldırmada etkili olacağı; Mıhc1-Türker ve Pala'nın (2018) vurguladığ 1 öğretmenlerin yeterliklerini arttırmaya katk1 sağlayacağı düşünülmektedir. Bu noktada öğretmenlerin meslek öncesinde lisans eğitimlerinde uzman akademisyenler ve deneyimli öğretmenlerden (Pala ve Türker, 2019) kodlama öğretimine ilişkin pedagojik bilgileri almaları ve yeterlik kazanmaları son derece önemlidir.

Sonuç olarak bu araştırmada öğretmenlerin kodlama öğretiminde kullandıkları araçlar, öğretim yöntemleri ve ölçme değerlendirme araçları ortaya konmuştur. Araştırma sonuçları doğrultusunda kodlama öğretiminde çeşitli araçların kullanımının öğrenme sürecindeki etkilerine ilişkin çalışmaların yapılabileceği, kodlama öğretiminde öğretim yöntem ve tekniklerinin kullanımına ilişkin araştırmalar ve uygulayıcılara dönük eğitimler verilebileceği düşünülmektedir. Diğer taraftan kodlama öğretiminde özellikle süreç değerlendirmesinde kullanılabilecek ölçme araçlarının analitik hale gelmesi önemli görülmektedir. Bu kapsamda araştırmacıların kodlama öğretiminde sürece dayalı ölçme ve değerlendirme araçları geliştirmelerinin ve üniversitelerin öğretmen topluluklarını destekleyerek öğretmenlerin profesyonel gelişimlerine destek olmasının yerinde olacağı değerlendirilmektedir. Ayrıca araştırma bulgularının K12 düzeyinde eğitim veren eğitimcilere kodlama öğretimi sürecini daha etkili hale getirmelerinde katkı sunması umulmaktadır.

$---$

Etik Kurul İzin Bilgisi: Bu araştırma, Ege Üniversitesi Bilimsel Araştırma ve Yayın Etiği Kurulunun 28/08/2018 tarihli 04/04 sayılı kararı ile alınan izinle yürütülmüşı̈̈r. 


\section{Kaynakça/References}

Abad, C. L. (2008). Learning through creating learning objects: Experiences with a class project in a distributed systems course. ACM SIGCSE Bulletin, 40(3), 255-259.

Akbıyık, C., \& Seferoğlu, S. S. (2012). Instructing ICT lessons in primary schools: Teachers' opinions \& applications. Educational Sciences: Theory \& Practice, 12(1), 405- 424.

Arabacıŏ̆lu, C., Bülbül, H. ve Filiz, A. (2007, Şubat). Bilgisayar programlama öğretiminde yeni bir yaklaşım. Akademik Bilişim 2007 Konferans1, Dumlupınar Üniversitesi, Kütahya. http://ab.org.tr/ab07/kitap/arabacioglu_bulbul_AB07.pdf adresinden elde edildi.

Armoni, M., \& Gal-Ezer, J. (2014). High school computer science education paves the way for higher education: The Israeli case. Computer Science Education, 24(2-3), 101-122. doi:10.1080/08993408.2014.936655

Armoni, M., Meerbaum-Salant, O., \& Ben-Ari, M. (2015). From scratch to "real" programming. ACM Transactions on Computing Education, TOCE, 14(4), 25. doi:10.1145/2677087

Au, W. K., \& Leung, J. P. (1992). Problem solving, instructional methods and Logo programming. Journal of Educational Computing Research, 7(4), 455-467.

Balanskat, A., \& Engelhardt, K. (2015). Computing our future: Computer programming and coding-priorities, school curricula and initiatives across Europe. Belgium: European Schoolnet.

Bashir, G. M. M., \& Hoque, A. S. M. L. (2016). An effective learning and teaching model for programming languages. Journal of Computers in Education, 3(4), 413-437. doi:10.1007/s40692-016-0073-2

Bell, T., Alexander, J., Freeman, I., \& Grimley, M. (2009). Computer science unplugged: School students doing real computing without computers. New Zealand Journal of Applied Computing and Information Technology, 13(1), 20-29.

Bers, M. U. (2017). Coding as a playground: Programming and computational thinking in the early childhood classroom. Oxon: Routledge. doi:10.4324/9781315398945

Chao, P. Y. (2016). Exploring students' computational practice, design \& performance of problem-solving through a visual programming environment. Computers \& Education, (95), 202-215. doi:10.1016/j.compedu.2016.01.010

Clements, D. H., \& Gullo, D. F. (1984). Effects of computer programming on young children's cognition. Journal of Educational Psychology, 76(6), 1051-1058.

Creswell, J. W., Plano Clark, V. L., Gutmann, M. L., \& Hanson, W. E. (2003). Advanced mixed methods research designs. In A. Tashakkori \& C. Teddlie, (Eds.), Handbook of mixed methods in social and behavioral research. (pp.209-240). Thousand Oaks, CA: Sage.

Encyclopædia Britannica (2020). Computer science, $\quad$ Retrieved from https://www.britannica.com/science/computer-science

Ersoy, H., Madran, R. O. ve Gülbahar, Y. (2011, Şubat). Programlama dilleri öğretimine bir model önerisi: Robot programlama. XIII. Akademik Bilişim Konferansı, Malatya, Türkiye. https://ab.org.tr/ab11/kitap/ersoy_madran_AB11.pdf adresinden elde edildi.

Fessakis, G., Gouli, E., \& Mavroudi, E. (2013). Problem solving by 5-6 years old kindergarten children in a computer programming environment: A case study. Computers \& Education, (63), 87-97. doi:10.1016/j.compedu.2012.11.016

Fokides, E. (2017). Students learning to program by developing games. Results of a year-long project in primary school settings. Journal of Information Technology Education: Research, (16), 475-505. doi:10.28945/3893

Forsythe, G. E. (1967). A university's educational program in computer science. Communications of the ACM, 10(1), 3-11.

García-Peñalvo, F. J., Reimann, D., Tuul, M., Rees, A., \& Jormanainen, I. (2016). An overview of the most relevant literature on coding \& computational thinking with emphasis on the relevant issues for teachers. Belgium: TACCLE3 Consortium. doi:10.5281/zenodo.165123

Grover, S. (2014). Foundations for advancing computational thinking: Balanced designs for deeper learning in an online computer science course for middle school students. Retrieved from http://purl.stanford.edu/cc869py7832 
Hansen, A. K., Iveland, A., Carlin, C., Harlow, D. B., \& Franklin, D. (2016). User-centered design in block-based programming: Developmental \& pedagogical considerations for children. In Proceedings of the 15th International Conference on Interaction Design and Children (pp. 147-156). doi:10.1145/2930674.2930699

Jenson, J., \& Droumeva, M. (2016). Exploring media literacy and computational thinking: A game maker curriculum study. The Electronic Journal of e-Learning, 14(2), 111-121.

John, M. S., \& Rani, M. S. (2015). Teaching Java programming on smartphone-pedagogy and innovation; Proposal of its ontology-oriented implementation. Procedia-Social and Behavioral Sciences, (176), 787-794. doi:10.1016/j.sbspro.2015.01.541

Kalelioğlu, F., \& Gülbahar, Y. (2014). The effects of teaching programming via Scratch on problem solving skills: A discussion from learners' perspective. Informatics in Education, 13(1), 33-50.

Kalelioğlu, F. ve Keskinkılıç, F. (2017). Bilgisayar bilimi eğitimi için öğretim yöntemleri. Y. Gülbahar (Ed.), Bilgi işlemsel düşünmeden programlamaya içinde (ss. 155-182). Ankara: Pegem Akademi. doi:10.14527/9786052411117.07

Kandemir, C. M. (2017). Metin tabanlı programlama. Y. Gülbahar(Ed.), Bilgi işlemsel düşünmeden programlamaya içinde(ss. 267-294). Ankara: Pegem Akademi. doi:10.14527/9786052411117.11

Kılıç, A. F. (2016). Uyum analizi [Correspondence analysis]. Yönetim Bilişim Sistemleri Ansiklopedisi, 3(1), 1-20.

KodlaManisa. (2020a, Nisan). Kodlamanisa Projesi. http://www.kodlamanisa.gov.tr adresinden elde edildi.

KodlaManisa. (2020b, Nisan). Unplugged kodlama nedir? https://www.kodlamanisa.gov.tr/unplugged-kodlama/ adresinden elde edildi.

Kong, S. C. (2016). A framework of curriculum design for computational thinking development in K-12 education. Journal of Computers in Education, 3(4), 377-394. doi:10.1007/s40692-016-0076-Z

Kong, S. C., Li, R. K. Y., \& Kwok, R. C. W. (2018). Measuring parents' perceptions of programming education in P-12 Schools: Scale development and validation. Journal of Educational Computing Research, 57(5), 1260-1280. doi:10.1177/0735633118783182

Korkmaz, Ö., Şahin, H., Çakır, R. ve Erdoğmuş, F. U. (2019). Bilişim teknolojileri öğretmenlerinin kodlamaya dönük tutumları, öz-yeterlilikleri ve kodlama öğretimi için kullandıkları yöntemler. Ondokuz Mayıs Üniversitesi Ĕgitim Fakültesi Dergisi, 38(2), $1-16 . \quad$ Retrieved from https://dergipark.org.tr/tr/pub/omuefd/issue/50852/612449

Kotini I., \& Tzelepi S. (2015). A gamification-based framework for developing learning activities of computational thinking. In T. Reiners \& L.Wood (Eds.), Gamification in Education and Business. Springer, Cham. https://doi.org/10.1007/978-3-319-10208-5_12

Kukul, V. ve Gökçearslan, Ş. (2014, Eylül). Scratch ile programlama eğitimi alan öğrencilerin problem çözme becerilerinin incelenmesi. https://goo.gl/6ucqn1 adresinden elde edildi.

Meerbaum-Salant, O., Armoni, M., \& Ben-Ari, M. (2011, June). Habits of programming in scratch. ITICSE'11 Proceedings of the 16th annual joint conference on Innovation and technology in computer science education, (168-172). New York: Association for Computing Machinery.

Mihc1-Türker, P. ve Pala, K. F. (2018). Ortaokul öğrencilerinin, öğretmenlerin ve öğrenci velilerinin kodlamaya yönelik görüşleri. İlköğretim Online, 17(4), 2013-2029. doi:10.17051/ilkonline.2019.506939

Milli Eğitim Bakanlı̆̆ı [MEB]. (2020, Nisan). Bilişim teknolojileri çerçeve programı. http://bilsem.meb.gov.tr adresinden elde edildi.

Mladenović, M., Boljat, I., \& Žanko, Ž. (2018). Comparing loops misconceptions in block-based and text-based programming languages at the K-12 level. Education and Information Technologies, 23(4), 1483-1500. doi:10.1007/s10639-017-9673-3

Nishida, T., Kanemune, S., Idosaka, Y., Namiki, M., Bell, T., \& Kuno, Y. (2009). A CS unplugged design pattern. Proceedings of the 40th ACM Technical Symposium on Computer Science Education, (p. 231). SIGCSE 09. doi:10.1145/1508865.1508951.

Nouri, J., Norén, E., \& Skog, K. (2018, March). Learning programming by playing and coding games in K-9. In 12th International Technology, Education and Development Conference, (pp. 7990-7995). Valencia, Spain. doi:10.21125/inted.2018.1916 
Özçakmak, Ş. (2014). Bilgisayar kullanımı çocukta bağımlılık yapar mı? http://www.haberturk.com/polemik/haber/973204-bilgisayar-kullanimi-cocukta-bagimlilik-yapar-mi? adresinden elde edildi.

Pala, F. ve Mihc1-Türker, P. (2019). Öğretmen adaylarının programlama eğitimine yönelik görüşleri. Kuramsal Eğitimbilim Dergisi, 12(1), 116-13. doi:10.30831/akukeg.399921

Papert, S. (1980). Mindstorms: Children, computers, and powerful ideas. New York: Basic Books.

Raab, J., Rasala, R., \& Proulx, V. K. (2000). Pedagogical power tools for teaching Java. ACM SIGCSE Bulletin, 32(3), 156-159.

Sabitzer, B. (2011, March). Neurodidactics-a new stimulus in ICT and computer science education. Conference paper. 5th International Technology, Education and Development Conference, Valencia, Spain.

Sayın, Z. ve Seferoğlu, S. (2016, Şubat). Yeni bir 21. yy. becerisi olarak kodlama eğitimi ve kodlamanın eğitim politikalarına etkisi. Akademik Bilişim 2016. Adnan Menderes Üniversitesi, Aydın. http://yunus.hacettepe.edu.tr/ Sadi/yayin/AB16_Sayin-Seferoglu_Kodlama.pdf adresinden elde edildi.

Sentance, S., \& Csizmadia, A. (2015). Teachers' perspectives on successful strategies for teaching Computing in school. In A. Brodnik \& C. Lewin (Eds.), IFIP TC3 Working Conference "A New Culture of Learning: Computing and next Generations”. Preliminary Proceedings (pp. 201-210). Lithuania, Vilnius University, [2016, October 1]. Retrieved from http://docplayer.net/16256814-Ifip-tc3-working-conference-a-newculture-of-learning- computing-and-next-generations.html

Uzgur, B. Ç. ve Aykaç, N. (2016). Bilişim teknolojileri ve yazılım dersi öğretim programının öğretmen görüşlerine göre değerlendirilmesi (Ege bölgesi örneği). Mustafa Kemal Üniversitesi Sosyal Bilimler Enstitüsü Dergisi, 13(34), 273-297.

Üçgül, M. (2017). Eğitsel robotlar ve bilgi işlemsel düşünme. Y. Gülbahar (Ed.), Bilgi işlemsel düşünmeden programlamaya içinde (ss. 295-317). Ankara: Pegem Akademi.

Webb, M., Davis, N., Bell, T., Katz, Y. J., Reynolds, N., Chambers, D. P., \& Sysło, M. M. (2017). Computer science in K-12 school curricula of the 21st century: Why, what and when? Education and Information Technologies, 22(2), 445-468. doi:10.1007/s10639-016-9493-x

Weinberg, A. E. (2013). Computational thinking: An investigation of the existing scholarship \& research. Retrieved from https://search.proquest.com/docview/1413309206?accountid=10699

Weintrop, D., \& Wilensky, U. (2015, June). To block or not to block, that is the question: Students' perceptions of blocks-based programming. Full paper, 14 International Conference on Interaction Design and Children, Medford, MA, USA. doi:10.1145/2771839.2771860

Williamson, B., Bergviken Rensfeldt, A., Player-Koro, C., \& Selwyn, N. (2019). Education recoded: Policy mobilities in the international 'learning to code'agenda. Journal of Education Policy, 34(5), 705-725. doi:10.1080/02680939.2018.1476735

Yeni, S. (2017). Bilgi işlemsel düşünme becerisi nasıl değerlendirilir? Y. Gülbahar (Ed.), Bilgi işlemsel düşünmeden programlamaya içinde (ss. 359-391). Ankara: Pegem Akademi.

Yıldırım, A. ve Şimşek, H. (2005). Sosyal bilimlerde nitel araştırma yöntemleri. Ankara: Seçkin Yayıncılık.

Yükseköğretim Kurulu [YÖK]. (2018). Bilgisayar ve Öğretim Teknolojileri Öğretmenliği Lisans Programı, http://yok.gov.tr/documents/10279/41805112/Bilgisayar_ve_Ogretim_Teknolojileri_Ogretmenligi_Lisans_ Programi.pdf adresinden elde edildi. 